\title{
Sulfide Immiscibility Induced by Wall-Rock Assimilation in a Fault-Guided Basaltic Feeder System, Franklin Large Igneous Province, Victoria Island (Arctic Canada)*
}

\author{
Ben Hayes, ${ }^{1,+, * * *}$ Jean H. Bédard, ${ }^{2}$ Matthew Hryciuk ${ }^{3}$ Boswell Wing, ${ }^{3}$ Peter Nabelek ${ }^{4}$ \\ William D. MacDonald ${ }^{5}$ AND C. JOHAN LissenberG ${ }^{1}$ \\ ${ }^{1}$ School of Earth and Ocean Sciences, Cardiff University, Park Place, Cardiff, United Kingdom CF10 3AT \\ ${ }^{2}$ Geological Survey of Canada, 490 de la Couronne, Québec City, Québec, Canada G1K 9A9 \\ ${ }^{3}$ Department of Earth and Planetary Sciences and GEOTOP, McGill University, 3450 University Street, \\ Montréal, Québec, Canada H3A OE8 \\ ${ }^{4}$ Department of Geological Sciences, University of Missouri, Columbia, Missouri 65211 \\ ${ }^{5}$ Department of Geological Sciences, State University of New York, Binghamton, New York 13902
}

\begin{abstract}
The Southern Feeder Dike Complex is part of the Franklin Large Igneous Province (LIP), exposed in the Minto Inlier of Victoria Island in the Canadian Arctic. Previous field and geochemical studies on the Franklin LIP considered its igneous rocks to be prospective for Fe-Ni-Cu mineralization. The Southern Feeder Dike Complex comprises a series of NW-SE-trending gabbroic intrusions and sedimentary hosts. Field and textural relationships show that the Complex intrusions were emplaced contemporaneously with Neoproterozoic normal faulting. Faulted contact zones correspond to prominent first derivative magnetic lineaments. Gabbroic dikes have intrusive contacts against brecciated country rock, and diabasic microxenoliths in basaltic matrices indicate multiple intrusive/brecciation events. Intrusive breccias are commonly overprinted by hydrothermal greenschist facies assemblages, with calcite + pyrite veins filling open spaces between breccia fragments. Late dikes emplaced into these heterogeneous breccias contain disseminated globular and net-textured sulfides suggesting that sulfide immiscibility was triggered on a local scale by assimilation of local wall rock. This inference is supported by elevated $\delta^{34} \mathrm{~S}$ values of sulfides in these dikes, consistent with assimilation of country rocks. Wall-rock assimilation would have been facilitated by fault-related brecciation and cataclasis, which would expose extensive xenolith surface areas to fresh magma. Gossanous and meter-scale semimassive sulfide showings associated with dikes and sills located upsection from the Southern Feeder Dike Complex suggest that immiscible sulfide liquids may have been flushed downstream (or upsection) during replenishment of composite dike systems. Fault-mediated melt ascent along northwest-southeast faults has been documented elsewhere in the Minto Inlier, providing equivalent opportunities for wall-rock assimilation and consequent triggering of sulfide immiscibility and sulfide melt redistribution. The evidence preserved in the Complex confirms the Fe-Ni-Cu potential of the Franklin LIP and informs current models of ore deposit formation in conduit-type magmatic plumbing systems.
\end{abstract}

\section{Introduction}

DIKE-LIKE magma conduits are dynamic systems that provide opportunities for magma-crust interaction (Naldrett, 1992; Li et al., 2000; Maier et al., 2001; Mungall, 2007; Ding et al., 2010; Hughes et al., 2015; Lightfoot and Evans-Lamswood, 2015 ) and are important sites of $\mathrm{Fe}-\mathrm{Ni}-\mathrm{Cu}$ mineralization (Naldrett, 1992; Ripley and Li, 2011). Economic conduit-type $\mathrm{Fe}-\mathrm{Ni}-\mathrm{Cu}$ deposits are typically associated with olivine-rich magmas (Li and Naldrett, 1999), commonly situated close to major crustal faults (Naldrett, 1992; Begg et al., 2010; Song et al., 2012; Lightfoot and Evans-Lamswood, 2015), generally hosted by (or related to) intrusive or extrusive facies that show a depletion in chalcophile elements (Naldrett, 1992), commonly emplaced into (or traverse) sulfur-bearing country rocks

${ }^{\circ}$ A digital supplement to this paper is available at http://economicgeology. org/ and at http://econgeol.geoscienceworld.org/.

${ }^{+}$Corresponding author: e-mail, ben.hayes@wits.ac.za

${ }^{*}$ Current address: School of Geosciences, University of the Witwatersrand, PO Wits, 2050, South Africa.
(Naldrett, 1992; Li et al., 2009), and may show field and/or geochemical evidence of interaction between magma and country rock (Ripley et al., 2003; Naldrett, 2004; Li et al., 2009; Keays and Lightfoot, 2010; Ganino et al., 2014). Most economic Fe$\mathrm{Ni}-\mathrm{Cu}$ deposits of this type are thought to have involved addition of external sulfur to a sulfur-undersaturated magma as a trigger for sulfur saturation and the formation of immiscible sulfide liquids. Other possible mechanisms to induce sulfide saturation include changing melt composition (Irvine, 1975; Czamanske and Moore, 1977; Wendlandt, 1982), decreasing temperature (Haughton et al., 1974), and/or decreasing $f_{\mathrm{O}_{2}}$ (Buchanan and Nolan, 1979; Liu et al., 2007). A hydraulic trap is commonly invoked, so as to concentrate economic volumes of immiscible sulfide liquids (Naldrett, 1992). A high ratio of silicate magma to sulfide liquid ( $R$ factor)is also needed to upgrade the metal tenor of immiscible sulfide liquids (Campbell and Naldrett, 1979). In conduit-type deposits, upgrading would most likely occur in open magmatic systems, whereas previously concentrated sulfide melt would see its metal tenor upgraded during magma throughflow (Naldrett, 1992, 2004). 
Examples of conduit-type $\mathrm{Fe}-\mathrm{Ni}-\mathrm{Cu}$ deposits include the Noril'sk-Talnakh intrusions in Siberia (Naldrett, 1992; Arndt, 2011), Voisey's Bay in Labrador (Naldrett et al., 2000; Ripley and $\mathrm{Li}, 2011$ ), and the Eagle deposit in northern Michigan (Ding et al., 2010). Each of these magma conduits is associated with cratonic margins, regional fault-systems, and is comprised of ultramafic-mafic intrusions with associated differentiated magmas. Petrological and geochemical evidence implies that magma-crust interaction triggered the formation of immiscible sulfide liquids in each of these magma conduits. Data on $\delta^{34} \mathrm{~S}$ isotopes are especially informative about incorporation of crustal sulfur, which has fractionated ${ }^{34} \mathrm{~S}-{ }^{32} \mathrm{~S}$ signatures in comparison to mantle sulfur (e.g. Fiorentini et al., 2012; Ripley and Li, 2013; Black et al., 2014), with evaporites having large positive $\delta^{34} \mathrm{~S}$ values and black shales typically showing negative $\delta^{34} \mathrm{~S}$ values. For example, $\delta^{34} \mathrm{~S}$ isotope values $(6-14 \%$ ) of mafic rocks at Noril'sk have been explained by the transfer of evaporite sulfur into the magma (Grinenko, 1985; Li et al., 2009). For deposits where external sulfur is considered to have triggered immiscibility, a key issue is how and where the sulfur was incorporated into the magma (Ripley et al., 2003; Ripley and Li, 2013).

The metallogenic setting of the Franklin Large Igneous Province (LIP) in northern Canada (Fig. 1) shares many similarities with economic conduit-type $\mathrm{Fe}-\mathrm{Ni}$-Cu deposits, such as Noril'sk (Jefferson et al., 1994). A Geological Survey of Canada mapping project $(2010,2011)$ aimed to further constrain the $\mathrm{Fe}-\mathrm{Ni}-\mathrm{Cu}$ potential of the Franklin LIP within the Minto Inlier on Victoria Island (Fig. 1), which has been considered prospective by previous investigations (Jefferson et al., 1994; Jowitt and Ernst, 2013). The extrusive component of the Franklin LIP, the Natkusiak flood basalts, has many native $\mathrm{Cu}$ showings (Jefferson et al., 1985). The context is reminiscent of the Keweenawan basalts, which hosted major native

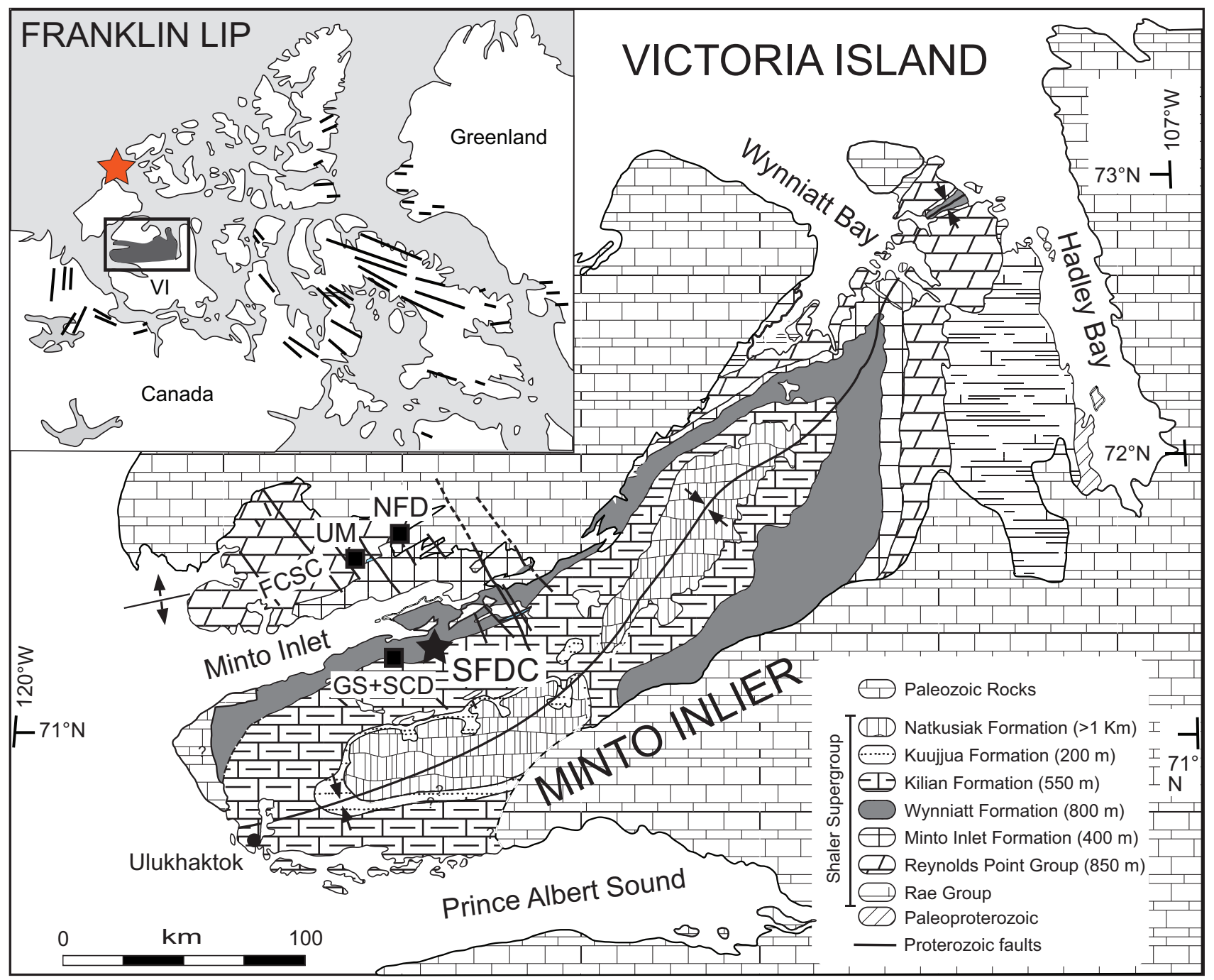

FIG. 1. A. Geologic map of Minto Inlier on Victoria Island after Bédard et al (2012). The location of the Southern Feeder Dike Complex is labeled, situated south of Minto Inlet and at the Wynniatt-Kilian Formation contact. Located $\sim 10 \mathrm{~km}$ westsouthwest of the Complex are the Gossan sill (GS) and the Sulfide City Dike (SCD). The Fort Collinson Sill Complex (FCSC) and the Uhuk Massif (UM) are also labeled, situated north of the Minto Inlier. Inset shows the extent of the Franklin LIP across northern Canada and Greenland. The red star marks the inferred location of the source of Franklin magma (Jowitt and Ernst, 2013). 
$\mathrm{Cu}$ deposits, and which are associated with magmatic sulfide mineralization in the coeval Duluth Complex (Miller et al., 2002).

In the Minto Inlier (Fig. 1), the Franklin igneous suite is dominated by mafic and ultramafic-mafic sills with subordinate NNW- to NW-trending feeder dikes (Bédard et al., 2012), that were emplaced into carbonate-clastic country rocks that, like Noril'sk, have horizons of massive sulfate evaporites. There are small $(0.1-3 \mathrm{~m}$; disseminated to semimassive) sulfide showings in the Franklin sills and dikes, as well as larger $(\sim 1-\mathrm{km}$ diameter $)$ surface gossans of uncertain origin (Peterson et al., 2014). A NNW- to NW-trending faultguided dike system with associated sulfide showings has been named the Southern Feeder Dike Complex (Bédard et al., 2012) and is the subject of this paper. The Complex preserves evidence of magma emplacement that was contemporaneous with regional-scale Neoproterozoic normal faulting, with field evidence suggesting that fault-related brecciation facilitated the ingestion of crustal sulfur into the magmas (Bédard et al., 2012). Motivated by this evidence, we carried out a field, geochemical, $\delta^{34} \mathrm{~S}$ isotope, and anisotropy of magnetic susceptibility study of the Complex in order to constrain how magmas were emplaced, how magmas interacted with host rocks, and how the associated sulfides formed. Our results bear on the Fe-Ni-Cu potential of the Franklin LIP and provide insights into the mechanisms involved in the generation of magmatic sulfides elsewhere, particularly those that operated in conduit-type magmatic plumbing systems.

\section{Regional Geology}

\section{Minto Inlier}

The Minto Inlier (Fig. 1) on Victoria Island in the Canadian Arctic is a NE-SW-trending window of Neoproterozoic Shaler Supergroup sedimentary rocks (Rainbird, 1993) capped by the Natkusiak flood basalts (Baragar, 1976; Jefferson et al., 1985; Dostal et al., 1986; Dupuy et al., 1995; Williamson et al., 2013). Coeval Franklin sills and dikes intrude the Shaler Supergroup (Baragar, 1976; Rainbird, 1993; Hulbert et al., 2005). These rocks were gently folded about ENE-trending axes, eroded, and then overlain by a Paleozoic clastic and carbonate sequence (Thorsteinsson and Tozer, 1962; Mathieu et al., 2013; Durbano et al., 2015), and subsequently cut by a prominent E- to NE-trending normal fault system (Bédard et al., 2012; Dewing et al., 2013). The Shaler Supergroup consists of a sequence of dominantly carbonate rocks (including abundant stromatolites) with subordinate clastics and sulfate evaporites, which are collectively interpreted to represent shallow-water intracontinental basin deposits (Young, 1981; Rainbird, 1993; Thomson et al., 2014). The Natkusiak flood basalts are the extrusive facies of the Franklin LIP ( 723-716 Ma: Heaman et al., 1992; Macdonald et al., 2010), which extends for $>2,500 \mathrm{~km}$ across northern Canada and west Greenland (Fig. 1). Regional dike swarms suggest the plume source to the Franklin LIP was located near Banks Island (Ernst and Jowitt, 2013). Geophysical data suggest that the edge of the Archean basement is located beneath the Minto Inlier (Harris 2014, unpub. report).

The geochemistry of the Franklin intrusions from Minto Inlier correlates with that of the Natkusiak flood basalts
(Bédard et al., 2013). At the base of the Natkusiak stratigraphy is a thin sequence of lavas that form rubbly vesicular flows. These primitive ( 10 wt \% MgO) lavas have light rare earth element (LREE)-enriched signatures $(\mathrm{Ce} / \mathrm{Yb}>8)$ and are referred to as type-1 magmas. Type-1 magmas correlate with a subset of sills characterized by olivine cumulate bases, which were interpreted to have formed by late olivine slurry replenishment (Hayes et al., 2015b). A thin unit of volcaniclastic deposits and mass flows separate the basal lavas from sheet-flow basalt sequences (Williamson et al., 2013), of which almost $1 \mathrm{~km}$ is preserved (Baragar, 1976). The sheetflow basalts are more evolved (lower $\mathrm{MgO}$ ) than the basal lavas but have lower LREE/HREE values $(\mathrm{Ce} / \mathrm{Yb}<8)$, and are referred to as type-2 magmas. Type- 2 magmas constitute the dominant population of diabasic and porphyritic-textured sills and dikes (including most of the Southern Feeder Dike Complex) emplaced within Shaler rocks.

First-derivative aeromagnetic maps (e.g., Kiss and Oneschuk, 2010) reveal prominent $\mathrm{NNW}^{-}$to NW-trending magnetic lineaments that often correspond to major, linear, topographic lows. Where exposures are adequate, many of these lineaments are seen to correspond to faults. Stratigraphic offsets indicate east- or west-side-down throws and parasitic structures generally indicate normal motions. Locally, breccias and cataclasites containing fragments of diabase or sedimentary wall rocks are cemented by basalt, indicating motion synchronous with the emplacement of Franklin magmas (Bédard et al., 2012). One example is the Uhuk Massif feeder system, located north of the Minto Inlet (Fig. 1) described in Bédard et al. (2012). The Southern Feeder Dike Complex (Fig. 2A) was briefly discussed in Bédard et al. (2012) as an example of a synfaulting dike system. Fieldwork in 2011 has greatly expanded our insight into the geology of the Complex, and these results are presented in this paper.

\section{Southern Feeder Dike Complex}

The Southern Feeder Dike Complex is situated $\sim 10 \mathrm{~km}$ south of the Minto Inlet (Fig. 1) and is located along a NNWto NW-trending magnetic lineament (Fig. 2B). On the kilometer scale, the area is characterized by a series of NW- or SE-trending gabbroic and sedimentary panels that are separated by prominent linear valleys or scarps, interpreted to be faults and/or intrusive contacts (Fig. 2A). The gabbroic outcrops comprise sills that form capping mesas, and dike-like bodies that are locally exposed in valleys, which commonly have a thick Quaternary cover. The intrusive rocks were emplaced at 1- to 2 -km paleodepth into southeasterly younging and shallowly SE-dipping bedded carbonates and evaporites of the Wynniatt and Kilian Formations of the Shaler Supergroup. We examined the Southern Feeder Dike Complex in five well-exposed zones along a $\sim 6-\mathrm{km}$ transect from the northwest to the southeast (i.e., moving upsection). We describe the field relationships of each zone in stratigraphic order (Zones D, C, B, E, A). Also labeled in Figure 1 are the locations of the Gossan Sill (GS) and the Sulfide City Dike (SCD), which both represent gabbroic bodies that contain sulfide mineralization and which were emplaced at a stratigraphic level close to the stratigraphically highest region of the Southern Feeder Dike Complex. These two occurrences will be discussed in future studies. 

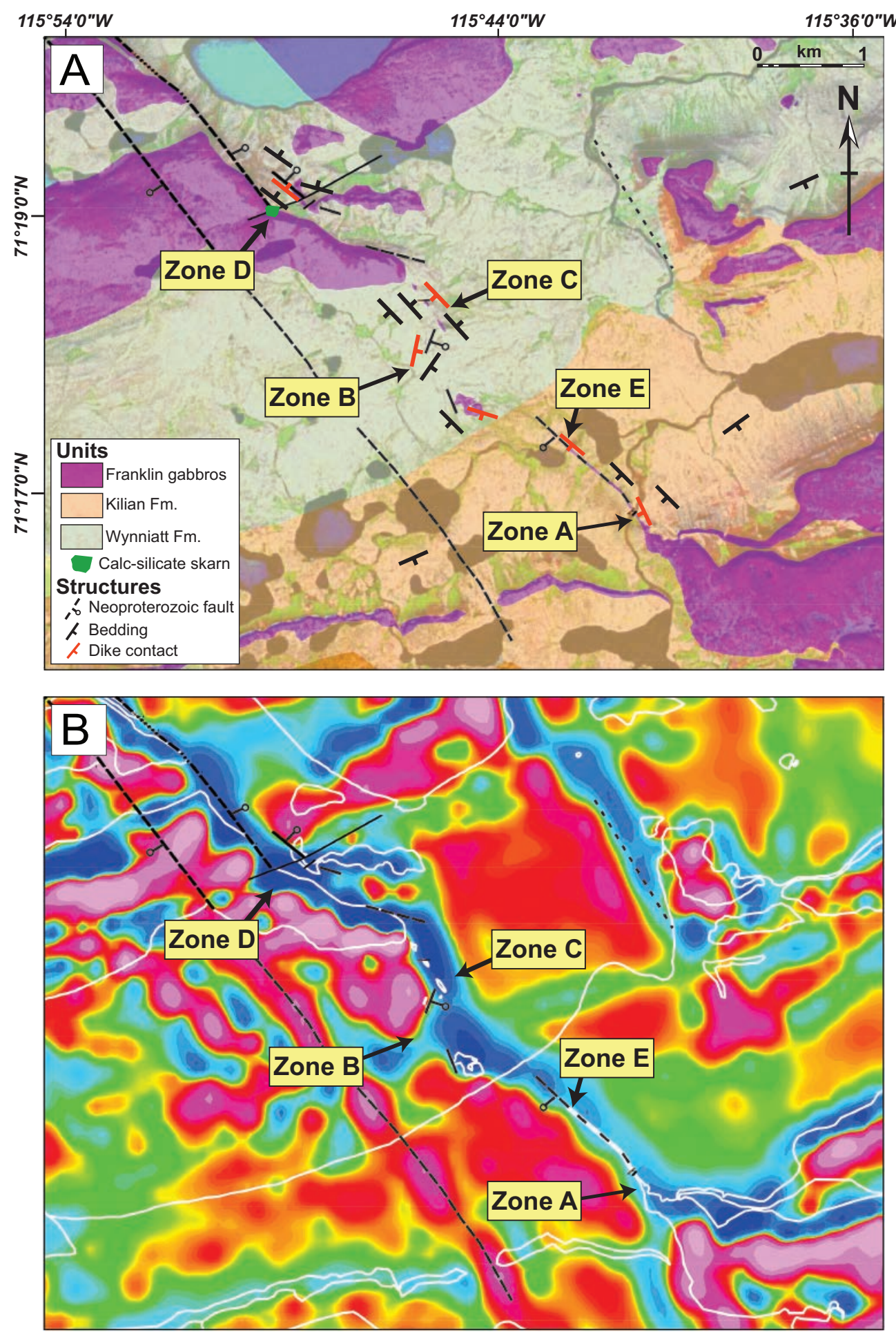

Fig. 2. A. Geological map of the Southern Feeder Dike Complex with each zone labeled. The Complex coincides with a first derivation NNW- to NW-trending magnetic anomaly (B). Regional bedding typically dips a few degrees toward the southeast, except for perturbations near the Complex.

Zone D: Zone $\mathrm{D}$ is at the northwestern end of the Southern Feeder Dike Complex (Fig. 3), corresponding to the lowest stratigraphic level examined. In this area, a large gabbroic body (SW end of Fig. 3) at the ridge top forms a capping mesa (Fig. 4A). Preserved contact relationships imply that this body is a sill (ca. $30 \mathrm{~m}$ thick) that extends for tens of kilometers toward the southwest. Contacts with the host Wynniatt Formation are poorly exposed, however, probably due to postintrusive motion on faults. The contact region of this capping sill ("b," Fig. 3) shows a bench of strongly recrystallized bedded 


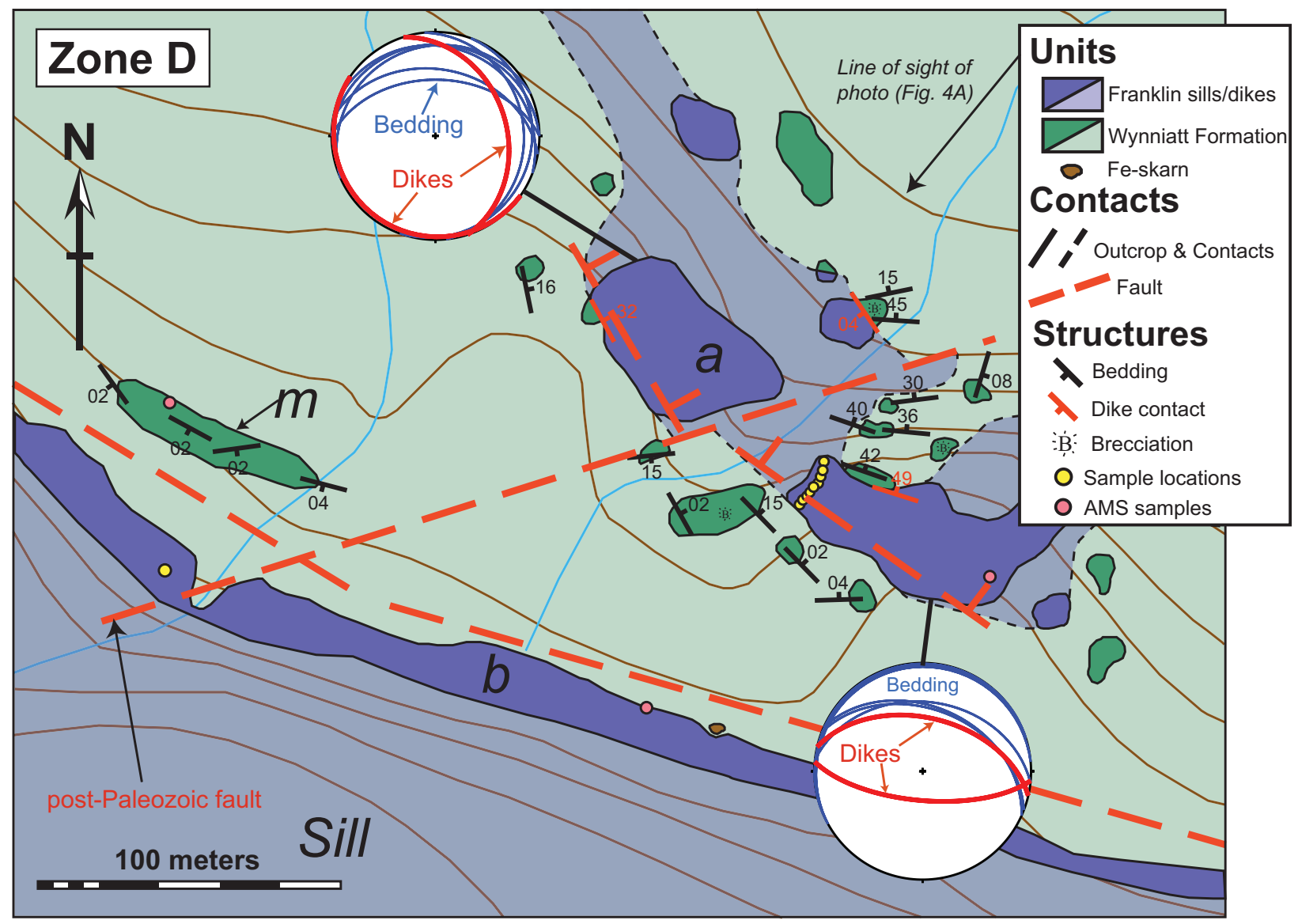

FIG. 3. A detailed geologic map of Zone D, showing the moderately dipping NNW- to NW-trending dike-like roof apophysis emplaced into moderately dipping Wynniatt Formation country rock. The line of sight for the field photo in Figure 4A is shown. See text for additional information.

marble (“m," Fig. 3) and a disrupted outcrop of interlayered calc-silicate and Fe oxide exoskarn rock. These facies closely resemble hanging-wall contact metamorphic rocks seen at the Uhuk Massif where there are fault-guided, upsection magmatic transgressions (Bédard et al., 2012; Nabelek et al., 2013). About $50 \mathrm{~m}$ away from this hidden fault contact toward the northeast, the bench-forming limestone is cut by an irregular 20-m-thick dike-like body of gabbro, ("a," Fig. 3). This gabbroic dike has chilled margins at both contacts, as well as internal chills. Bedding dip in the host Wynniatt Formation increases markedly toward the margins of this gabbro dike (from $5^{\circ} \rightarrow 70^{\circ}$ ), with drag fold polarity indicating northeast-side-down motion on a NNW- to NW-trending fault (Fig. 3). The host Wynniatt Formation adjacent to the dike is strongly recrystallized as well as heavily fractured and brecciated. We interpret this part of Zone D to be a downdropped hanging-wall limestone panel, with magma injected into parasitic faults to form a dike-like gabbroic roof apophysis in the downdropped panel similar to what was seen at the Uhuk Massif (Bédard et al. (2012). Figure 5 is a schematic block diagram illustrating the geometric relationships between the fault-guided feeder dike and the sill at Zone D.

Zone C: Zone C (Fig. 6) is situated $\sim 2 \mathrm{~km}$ to the southeast of Zone $\mathrm{D}$, along the same prominent aeromagnetic lineament (Fig. 2B). Limited exposures reveal a 20 -m-thick
NNW-trending gabbroic dike that has steeply dipping margins $\left(\sim 75^{\circ}\right.$ to the $\left.\mathrm{SW}\right)$, with a chilled margin preserved on the western side (Fig. 6). The Wynniatt Formation in contact with this chilled margin is heavily fractured and bedding increases in dip toward the dike (Fig. 6: up to $\sim 27^{\circ}$ to the $\mathrm{NE}$ ). The dip directions on either side of the gabbroic dike indicate northeast-side-down motion on a fault, as for Zone D. There is a thinner $(\sim 1 \mathrm{~m})$, parallel, subvertical $\left(\sim 85^{\circ}\right.$ dip $)$ dike that appears to merge into the thicker dike over a $\sim 15-\mathrm{m}$ distance (Fig. 6). The gabbroic body at Zone $\mathrm{C}$ is interpreted to be an extension of the main gabbroic intrusion of Zone D ("b," Fig. 3).

Zone B: Zone B (Fig. 7) is located $\sim 0.5 \mathrm{~km}$ to the southeast of Zone C (Fig. 2A). A rubbly mound ( $\sim 20 \mathrm{~m}$ thick) of dark, NNW- to NW-trending gabbroic rock can be seen at the poorly exposed northeastern end of Zone B. No contacts are preserved, but the thickness and orientation of the gabbro mound, as well as its proximity to Zone C, suggests it is a continuation of the Zone $\mathrm{C}$ dike. At the southwest corner of Zone B (Fig. 7) there are several, thinner ( 0.5- to 2-m thick) $\mathrm{N}$ - to NNE-trending dikes, which are oblique to the larger NNW- to NW-trending dike. Some of these thinner dikes can be traced for hundreds of meters through the host Wynniatt Formation and may connect to the larger NNW- to NWtrending dike. Bedding in the Wynniatt Formation limestone 

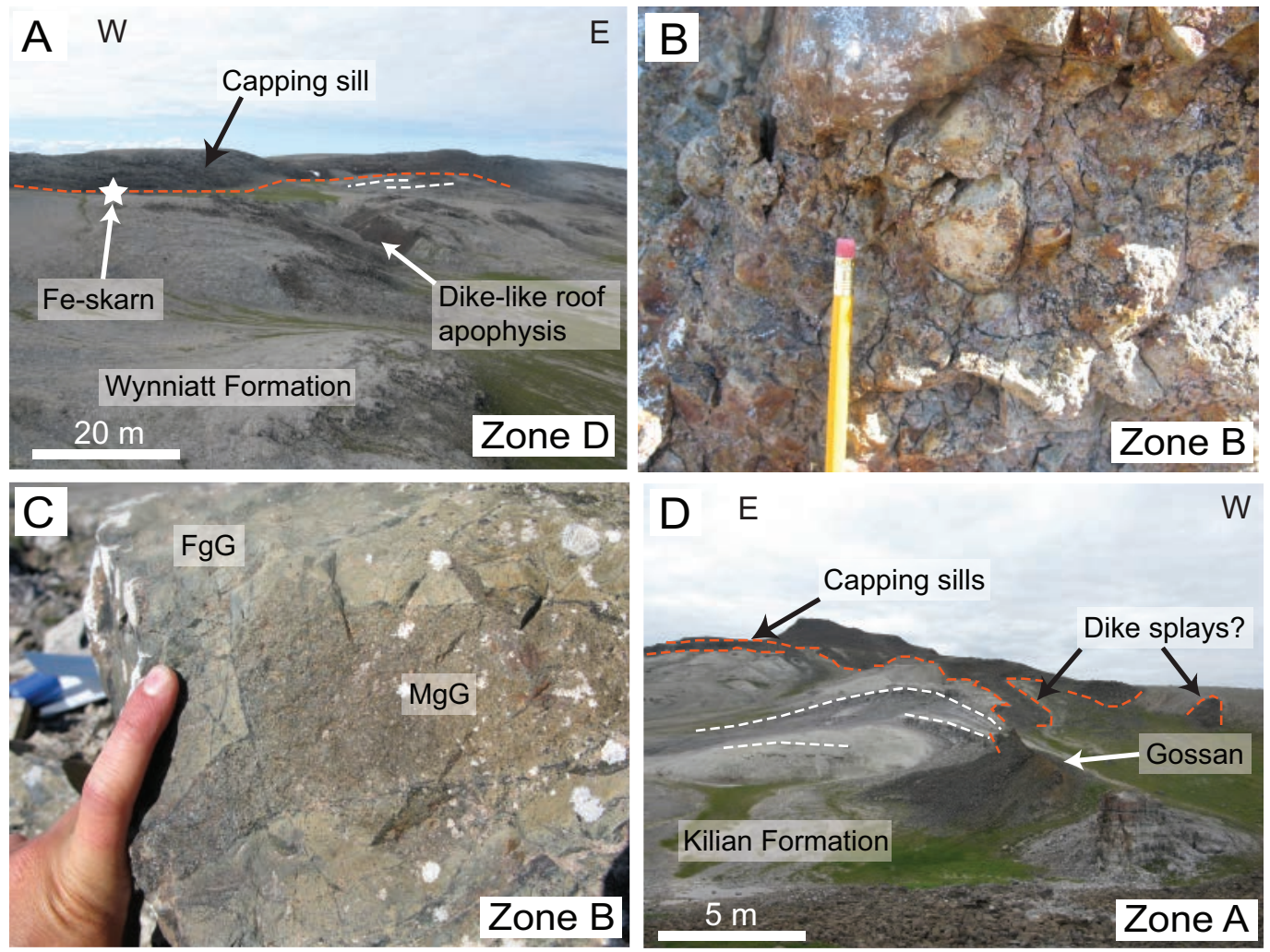

Fig. 4. A. Field photo of Zone D, showing the dike-like roof apophysis feeding toward the capping sill (dashed red line shows inferred contact region and dashed white lines show gently dipping Wynniatt Formation strata adjacent to the sill). B. Brecciated and Fe-stained Wynniatt Formation country rocks at Zone B (pencil is $5 \mathrm{~cm}$ ). C. Igneous breccia within the dike propagator tips at Zone B. Fine-grained, phyric basalt $(\mathrm{FgG})$ hosts xenoliths of microdiabasic sulfide-bearing gabbro (MgG). The dike propagator tips have a green coloration, possibly because of greenschist grade alteration. D. Field photo of Zone A showing the steeply dipping dike feeding and splaying toward the capping sills (dashed red lines define gabbroic outcrop). The Kilian Formation bedding dips steeply toward the dike (dashed white lines). The dike is gossan stained (labeled) and dips toward the southwest, with the dark material extending toward the viewer being talus of basalt deposited on limestone. It is unclear from the outcrop which sill the dike feeds into.

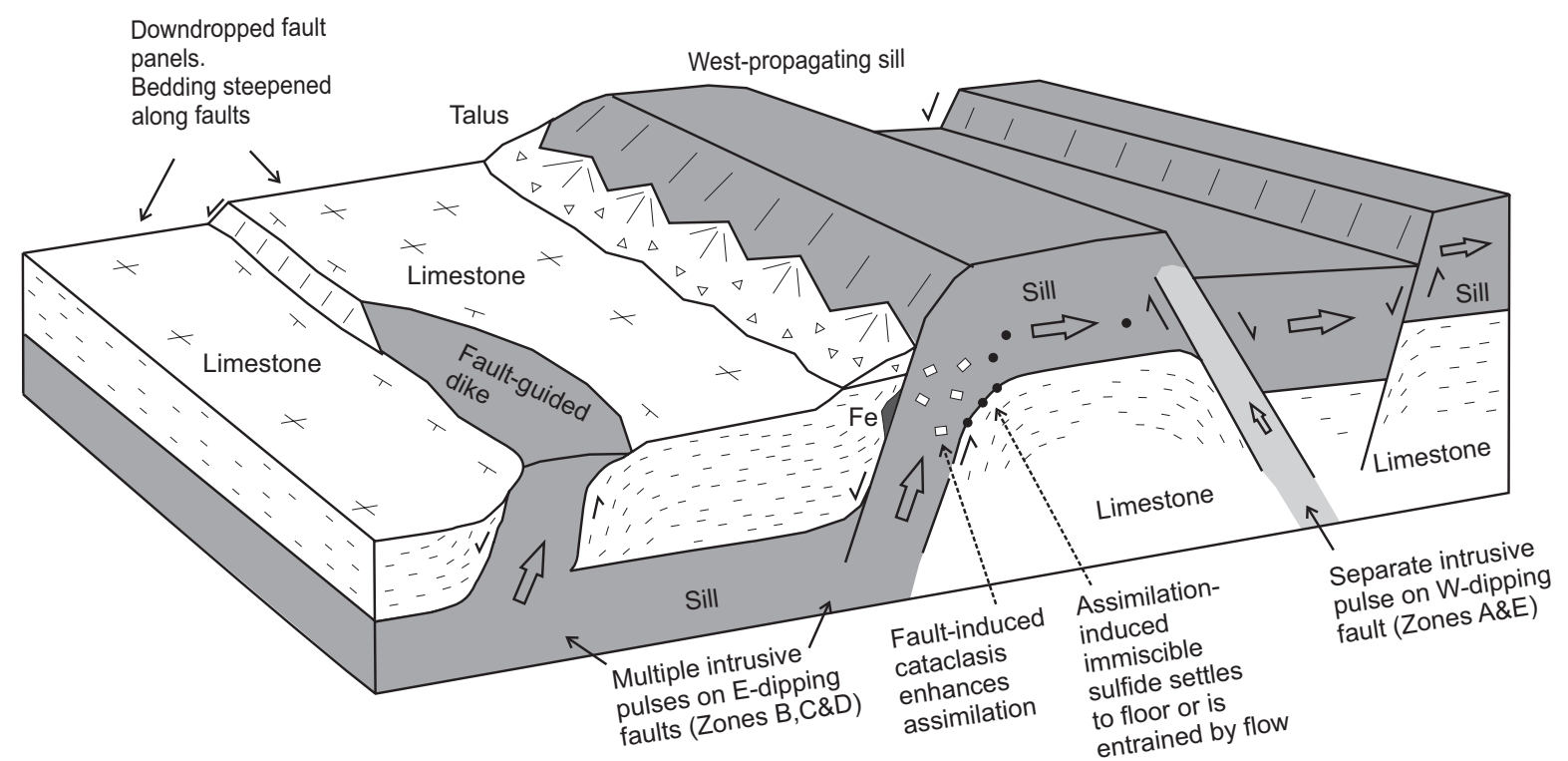

Fig. 5. Three-dimensional block diagram (view toward the south), showing the field relationships preserved at Zone D. "Fe" is a small Fe-rich exoskarn generated as per Bédard et al. (2012), formed by expulsion of residual Fe-rich hydrous fluids from crystallizing sills. Bedding orientation in limestone represented by dashes. Black dots are immiscible sulfide induced by assimilation of limestone in faults. 


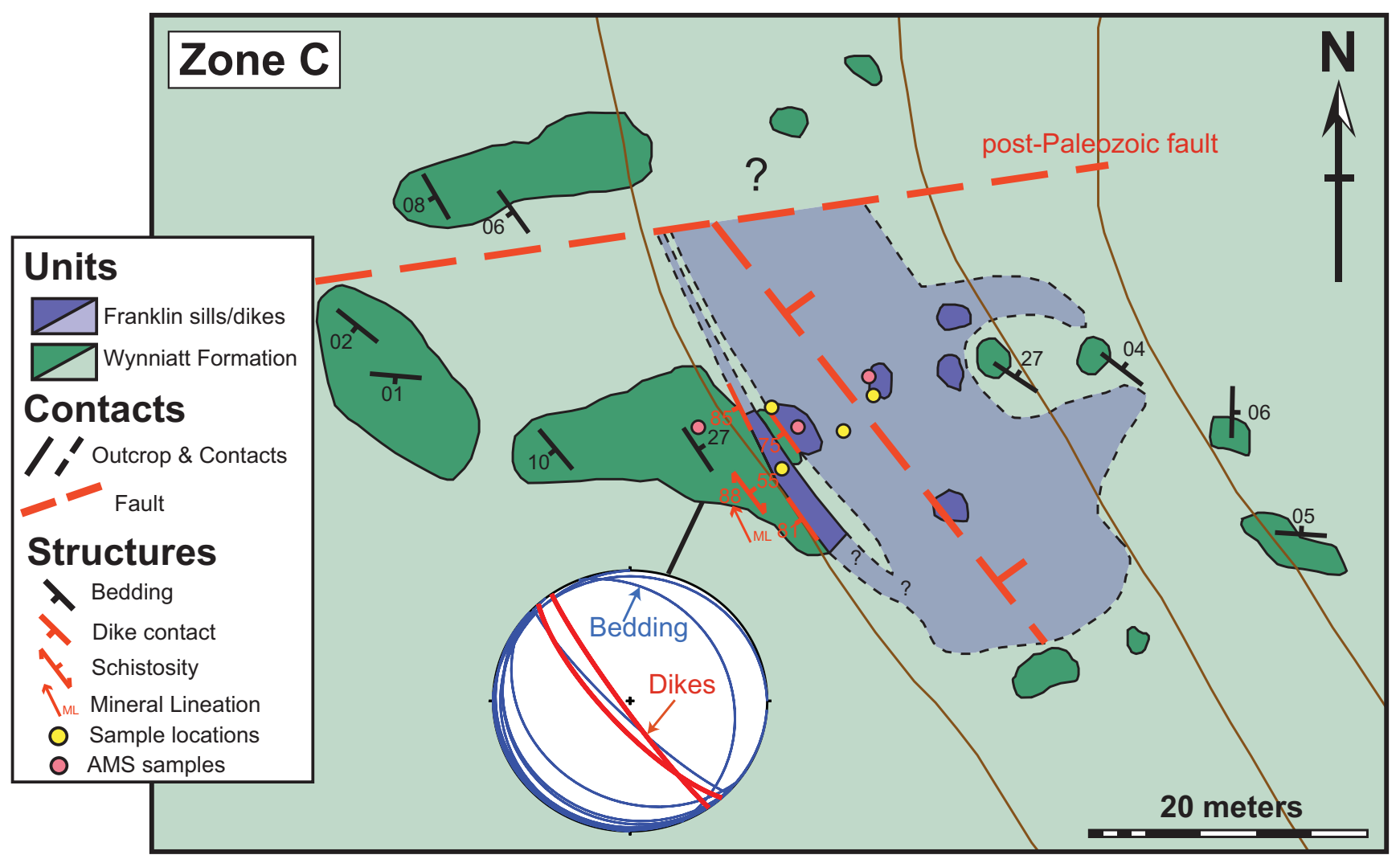

FIG. 6. A detailed geologic map of Zone C, showing the dike and local Wynniatt Formation bedding perturbations.

hosting the thinner dikes dips (up to $\sim 45^{\circ}$ ) toward the southeast and is commonly brecciated (Fig. 4B), with veins filled by calcite, prehnite, quartz, pyrite, and sparse chalcopyrite. The thin N- to NNE-trending dikes intrude the brecciated country rocks, and we infer them to be dike propagator tips that were emplaced into an active fault. In places, the breccias are igneous, with fine-grained diabasic microxenoliths cemented by aphanitic to fine-grained sparsely phyric basalt (Fig. 4C). Many of these breccias have a distinctly green coloration (Fig. 4C), indicating a strong greenschist-grade hydrothermal overprint that may have been driven by heat derived from dike emplacement. These greenschist facies breccias are cut by brown-weathered, weakly altered, and locally brecciated dikes, which appear to represent the youngest igneous event. These late dikes and breccias commonly contain disseminated magmatic sulfides, typically pyrite, pyrrhotite, and minor chalcopyrite.

Zone E: Zone E (Fig. 8A) is located midway between Zones $\mathrm{B}$ and $\mathrm{A}$ (Fig. 2A), and was discovered later than either of these two areas. We did not create a detailed map of Zone $\mathrm{E}$ because of the limited outcrop size (Fig. 8A). Zone E consists of a 20-m-thick NNW-trending gabbroic body emplaced into the Kilian Formation. Both margins of the gabbroic body are preserved, dipping very steeply toward the southwest $\left(\sim 80^{\circ}\right)$, and both are chilled contacts. This gabbroic body is interpreted to be a dike, which is parallel to the NNW-trending dikes of Zones D, C, and B, and falls along the extension of the Zone A dike (see below). The host Kilian Formation, near to the dike margins, is discolored (Fig. 8B), has steeper dips $\left(\sim 40^{\circ}\right.$ to the SW), and is heavily brecciated, with the fractures containing coarse ( 1-cm-sized) pyrite and calcite. Parasitic folds with NW-trending hinge lines are observed up to $\sim 10 \mathrm{~m}$ away from the dike contact (Fig. 8B). The deflection of the Kilian Formation bedding indicates southwest-side-down motion on a NNW-trending fault, the opposite sense to Zones D and C.

Zone A: Zone A (Fig. 9) is the southeastern end of the Southern Feeder Dike Complex and represents the highest stratigraphic level of the Complex that we have examined. A 20-m-thick gabbroic dike that trends NNW-NW has chilled margins against Kilian Formation sulfate evaporites that dip $\sim 80^{\circ}$ to the southwest (Fig. 4D). The dike is slightly offset $(<10 \mathrm{~m})$ by ENE-trending post-Paleozoic faults (Fig. 9). Bedding dip in the host rocks increases (up to $\sim 32^{\circ}$ to the $\mathrm{SW}$ ) at dike margins, indicating southwest-side-down motion on a NNW- to NW-trending fault, as for Zone E. We interpret the Zone A dike to be a direct continuation of the Zone E dike, which is offset from the trend of the Zones B, C, and $\mathrm{D}$ fault and may represent a separate fault strand (Fig. 2A). The dike at Zone A contains disseminated sulfides (mostly pyrite, pyrrhotite, and chalcopyrite) at its margin, as well as sulfide staining in its core (Fig. 4D). The dike appears to terminate where it merges with a set of conformable gabbroic sills (Figs. 2A, 4D). Two sills are well developed toward the northeast, but only one, poorly exposed sill can be traced toward the southwest. The junction of these two sets of sills with the Zone A dike is rubbly and poorly exposed (Fig. 4D), such that we cannot ascertain from field relationships if the dike fed the sills. 


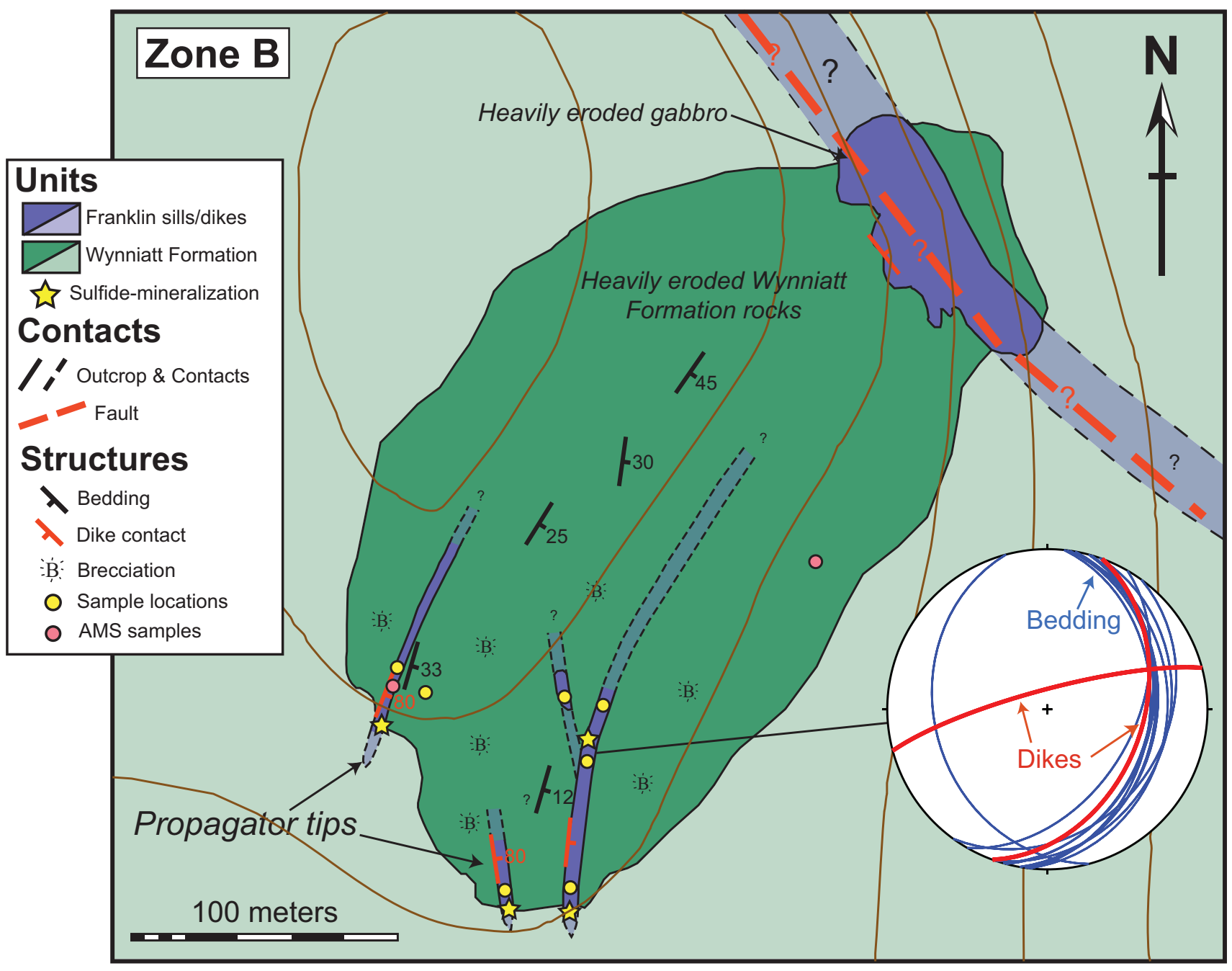

FIG. 7. A detailed geologic map of Zone B, showing the inferred location of the main NNW- to NW-trending dike as well as the N- to NNE-trending dike propagator tips that extend toward the south into brecciated Wynniatt Formation country rock.
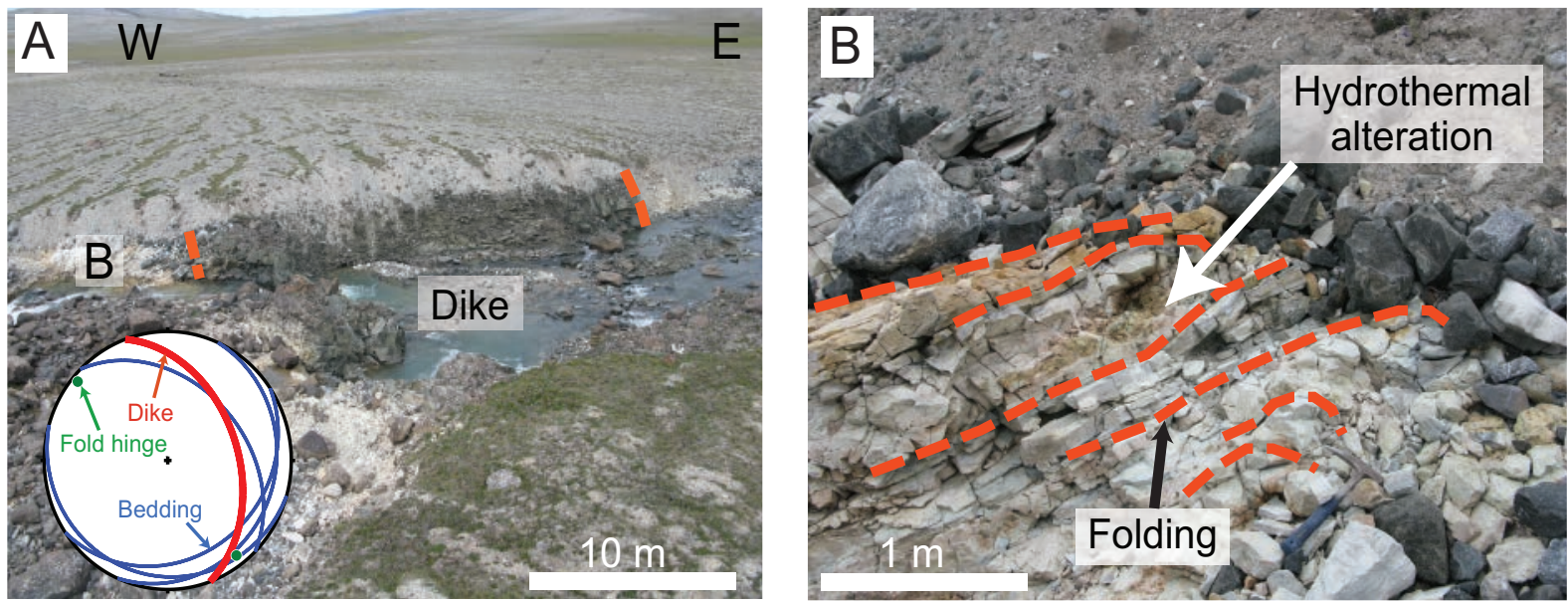

Fig. 8. A. Field photo of Zone E showing the dike outcrop (dashed red lines show igneous contacts). The location of photo $\mathrm{B}$ is shown at the western margin of the dike. B. Folded and discolored Kilian Formation bedding at the western margin of the dike. Fold hinge lines trend northwest, parallel to the dike. 


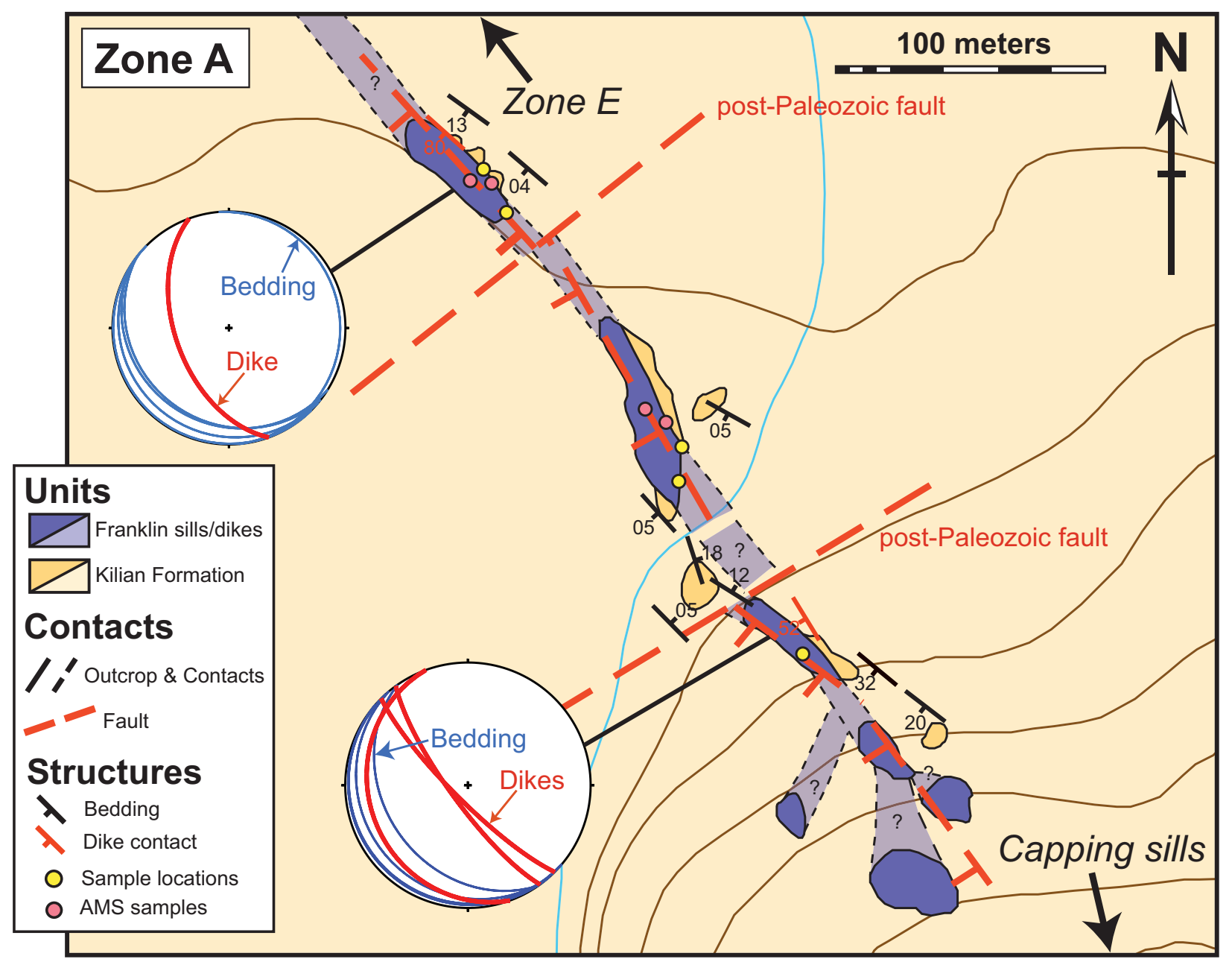

FIG. 9. A detailed geologic map of Zone A, showing an inferred continuous dike that splays toward two capping sills. The local Kilian Formation (sulfate-bearing) bedding is significantly perturbed near to where the dike splays.

\section{Analytical Methods}

Bulk-rock major and trace elements (Table A1) were obtained using inductively coupled plasma-optical emission spectrometry (ICP-OES) and ICP-mass spectrometry (MS) at both Cardiff University (UK), and IRNS-ETE laboratories in Québec City (Canada). The lithium metaborate fusion method was used at Cardiff University (full method details are in Hayes et al., 2015a). For full details of the methods used at INRS-ETE, see Leclerc et al. (2011). Platinum group element (PGE) contents of bulk-rock samples (Table A1) were obtained using Ni sulfide fire assay, followed by ICP-MS, at Cardiff University (Huber et al., 2001; McDonald and Viljoen, 2006). Sulfur isotope analyses were conducted in the Stable Isotope Laboratory of the Earth and Planetary Sciences Department at McGill University in Montréal (Canada). Full details of the methods used are provided in Hryciuk et al. (in prep.) and Southern Feeder Dike Complex data are provided in Table 1 as $\delta^{34}$ S values (\%o relative to Vienna Canyon Diablo Troilite, VCDT).

Anisotropy of magnetic susceptibility fabrics was measured at the State University of New York, Binghamton (US). Oriented blocks were taken at 17 sites along the Southern Feeder
Dike Complex using magnetic and solar compasses, 11 sites were in dikes, with six in adjacent sills. Typically five cores were drilled from each block, producing 85 oriented cores in total. The anisotropy of magnetic susceptibility of each core was measured using the AGICO KLY-3 Kappabridge susceptibility meter. Anisotropy of magnetic susceptibility data for the Southern Feeder Dike Complex is provided in Table 2.

\section{Petrography}

There are a variety of igneous and country-rock facies preserved in the Southern Feeder Dike Complex, including chilled intrusive contacts, medium-grained diabasic to gabbroic rocks, and brecciated host rocks, most of which show some hydrothermal overprint. Chilled contacts typically grade inward over a few centimeters to medium-grained diabasic facies.

At Zone D, the capping sill is composed of subophitic gabbro with euhedral, plagioclase crystals contained in anhedral clinopyroxene oikocrysts (Fig. 10A). Minor $(<15 \%)$ olivine and interstitial ilmenite-magnetite are also present. The gabbroic dike/roof apophysis ("a," Fig. 3) has a chilled margin that is microphyric with olivine and clinopyroxene phenocrysts 
TABLE 1. Sulfur Isotope Data

\begin{tabular}{|c|c|c|c|c|c|c|c|}
\hline Zone & Sample ID & Lithology & $\begin{array}{l}\text { Distance from } \\
\text { intrusive contact }(\mathrm{m})\end{array}$ & $\delta^{34} \mathrm{~S}(\mathrm{VCDT})$ & $\mathrm{S}$ (wt \%) & $\mathrm{Ni}(\mathrm{ppm})$ & $\mathrm{Cu}$ (ppm) \\
\hline $\mathrm{D}$ & MH123A1 & Wynniatt Fm & NA & 7.41 & 0.17 & 16 & 12 \\
\hline $\mathrm{D}$ & MH123B1 & Gabbro & NA & 2.98 & 0.077 & 132 & 189 \\
\hline $\mathrm{D}$ & MH126A1 & Gabbro & NA & 4.54 & 0.078 & 110 & 166 \\
\hline $\mathrm{D}$ & MH127A1 & Wynniatt Fm & NA & 11.47 & 0.30 & b.d.l. & b.d.l. \\
\hline $\mathrm{D}$ & MH128A1 & Gabbro & NA & 2.74 & 0.091 & 125 & 161 \\
\hline $\mathrm{C}$ & 11BH239A2 & Gabbro & NA & 10.601 & 0.339 & 48.8 & 181.6 \\
\hline $\mathrm{C}$ & 11MH131A2 & Gabbro & NA & 8.610 & 0.045 & 67.3 & 129.5 \\
\hline B & BH188A1 & Wynniatt Fm & NA & 19.55 & 0.18 & 9 & b.d.l. \\
\hline B & BH193A1 & Gabbro & NA & 4.82 & 0.576 & 105 & 266 \\
\hline B & BH195A1 & Gabbro & NA & 12.56 & 0.392 & 117 & 313 \\
\hline B & BH196A1 & Wynniat Fm & NA & 12.74 & 0.27 & b.d.l. & b.d.l. \\
\hline B & BH197A1 & Gabbro & NA & 8.24 & 0.244 & 78 & 178 \\
\hline B & 11BH210A1 & Gabbro & NA & 8.359 & 0.536 & 153.2 & 18.3 \\
\hline B & 11BH207A1 & Gabbro & NA & 8.884 & 0.727 & 116.2 & 22.4 \\
\hline $\mathrm{B}$ & 11BH209A1 & Gabbro & NA & 11.091 & 0.097 & 116.5 & 18.1 \\
\hline B & 11BH185A1 & Gabbro & NA & 13.885 & 0.272 & 58.9 & 85.9 \\
\hline B & 11BH185A2 & Gabbro & NA & 11.426 & 0.081 & 67.6 & 104.3 \\
\hline B & 11BH197A3 & Wynniat Fm & NA & 17.239 & $>1.0$ & 32.6 & 42.4 \\
\hline B & 11BH197A4 & Wynniat Fm & NA & 16.000 & $>1.0$ & 33.1 & 109.0 \\
\hline $\mathrm{E}$ & ВН366B1 & Gabbro & -0.2 & 9.74 & 0.091 & 112 & 158 \\
\hline $\mathrm{E}$ & ВH366B1\#2 & Gabbro & -0.2 & 10.39 & 0.091 & 112 & 158 \\
\hline $\mathrm{E}$ & ВН366B1\#3 & Gabbro & -0.2 & 10.35 & 0.091 & 112 & 158 \\
\hline $\mathrm{E}$ & 11BH372A1 & Gabbro & Dike core & 2.743 & 0.019 & 44.5 & 150.8 \\
\hline $\mathrm{E}$ & BH371A1 & Kilian Fm & 16.96 & 16.96 & 0.13 & 15 & 8 \\
\hline $\mathrm{E}$ & ВН369A1 & Kilian Fm & 17.57 & 17.57 & 0.26 & 10 & 5 \\
\hline $\mathrm{E}$ & BH368A1 & Kilian Fm & -5.06 & -5.06 & 0.28 & b.d.l. & b.d.l. \\
\hline $\mathrm{E}$ & BH367A1 & Kilian Fm & 17.15 & 17.15 & 0.43 & 7 & 9 \\
\hline $\mathrm{E}$ & BH365A1 & Kilian Fm & 24.06 & 24.06 & 0.92 & 6 & 27 \\
\hline A & BH167A4 & Gabbro & -22.7 & 8.86 & 0.076 & 88 & 204 \\
\hline A & BH162A1 & Gabbro & -13.9 & 5.03 & 0.070 & 121 & 162 \\
\hline A & BH162A2 & Gabbro & -4.9 & 8.00 & 0.074 & 96 & 179 \\
\hline A & BH164A1 & Kilian Fm & 9.5 & 19.06 & 0.13 & b.d.l. & 7 \\
\hline A & BH164A2 & Kilain Fm & 13.2 & 21.50 & 0.21 & 15 & 162 \\
\hline A & BH166A1 & Kilian Fm (evaps) & 17 & 31.77 & 17.4 & b.d.l. & 11 \\
\hline A & BH166A1\#2 & Kilian Fm (evaps) & 17 & 31.92 & 17.4 & b.d.l. & 11 \\
\hline A & BH166A2 & Kilian Fm (evaps) & 35 & 32.59 & 17.4 & b.d.l. & b.d.l. \\
\hline
\end{tabular}

Notes: b.d.l. = below detection limit, Evaps = evaporites, Fm $=$ formation, VCDT $=$ Vienna Canyon Diablo Troilite

TABLE 2. Anisotropy of Magnetic Susceptibility Data

\begin{tabular}{lccccc}
\hline \hline Site No. & Zone & Dike(D)/Sills $($ S $)$ & K1 & K2 & K3 \\
\hline SFDC 1 & A & D & $341 / 31$ & $121 / 52$ & $239 / 20$ \\
SFDC 2 & A & D & $163 / 68$ & $121 / 52$ & $056 / 07$ \\
SFDC 3 & A & D & $178 / 64$ & $333 / 24$ & $067 / 10$ \\
SFDC 4 & A & D & $112 / 51$ & $281 / 38$ & $015 / 05$ \\
SFDC 5 & B & D & $297 / 16$ & $192 / 41$ & $044 / 45$ \\
SFDC 6 & B & S & $065 / 23$ & $232 / 66$ & $333 / 05$ \\
SFDC 7 & B & D & $211 / 50$ & $359 / 35$ & $101 / 16$ \\
SFDC 8 & C & D & $253 / 64$ & $125 / 17$ & $029 / 19$ \\
SFDC 9 & C & D & $219 / 64$ & $006 / 22$ & $101 / 13$ \\
SFDC 10 & C & D & $158 / 65$ & $342 / 25$ & $251 / 02$ \\
SFDC 11 & C-D & S & $138 / 16$ & $267 / 65$ & $043 / 18$ \\
SFDC 12 & C-D & S & $142 / 11$ & $239 / 25$ & $029 / 61$ \\
SFDC 13 & D & S & $325 / 04$ & $056 / 12$ & $216 / 77$ \\
SFDC 14 & D & S & $156 / 08$ & $032 / 76$ & $248 / 11$ \\
SFDC 15 & D & S & $285 / 16$ & $018 / 14$ & $147 / 69$ \\
SFDC 16 & D & D & $244 / 67$ & $154 / 00$ & $063 / 23$ \\
SFDC 17 & D & D & $278 / 36$ & $038 / 35$ & $158 / 35$ \\
& & & & &
\end{tabular}

Notes: Five specimens were measured at each site $($ total $=85), \mathrm{K} 1, \mathrm{~K} 2$, and $\mathrm{K} 3$ are expressed as declination/inclination

C-D = samples were taken at small outcrops between Zones C and D residing in a very fine grained groundmass. This chilled margin grades into medium-grained gabbro that is texturally identical to the capping sill gabbro, with intergrown plagioclase and clinopyroxene and isolated olivine crystals. An internal chill within the gabbroic roof apophysis is very similar to the outer chilled margin with sparse clinopyroxene and plagioclase phenocrysts (no olivine was observed in the internal chill).

The Zone C dike is very similar to the gabbroic roof apophysis at Zone D. A chilled margin grades into a medium-grained gabbro. However, at Zone $\mathrm{C}$ the dike contains interstitial-textured olivine (Fig. 10B).

At Zone B, heavily brecciated Wynniatt Formation limestones (Fig. 4B) surround narrow dikes that we interpret to be dike propagator tips (Fig. 4C), with fractures/veins containing abundant calcite and hydrothermal pyrite crystals up to $1 \mathrm{~cm}$ in size. Veins also contain prehnite, quartz, and sparse chalcopyrite. The brecciated limestone is crosscut by the dike propagator tips, which themselves are brecciated by younger basaltic dikes. These brecciated propagator tips are composed of diabasic microxenoliths, which are cemented by microphyric basalt (Fig. 10C) that contains clinopyroxene and plagioclase microphenocrysts (Fig. 10I). The diabasic microxenoliths 


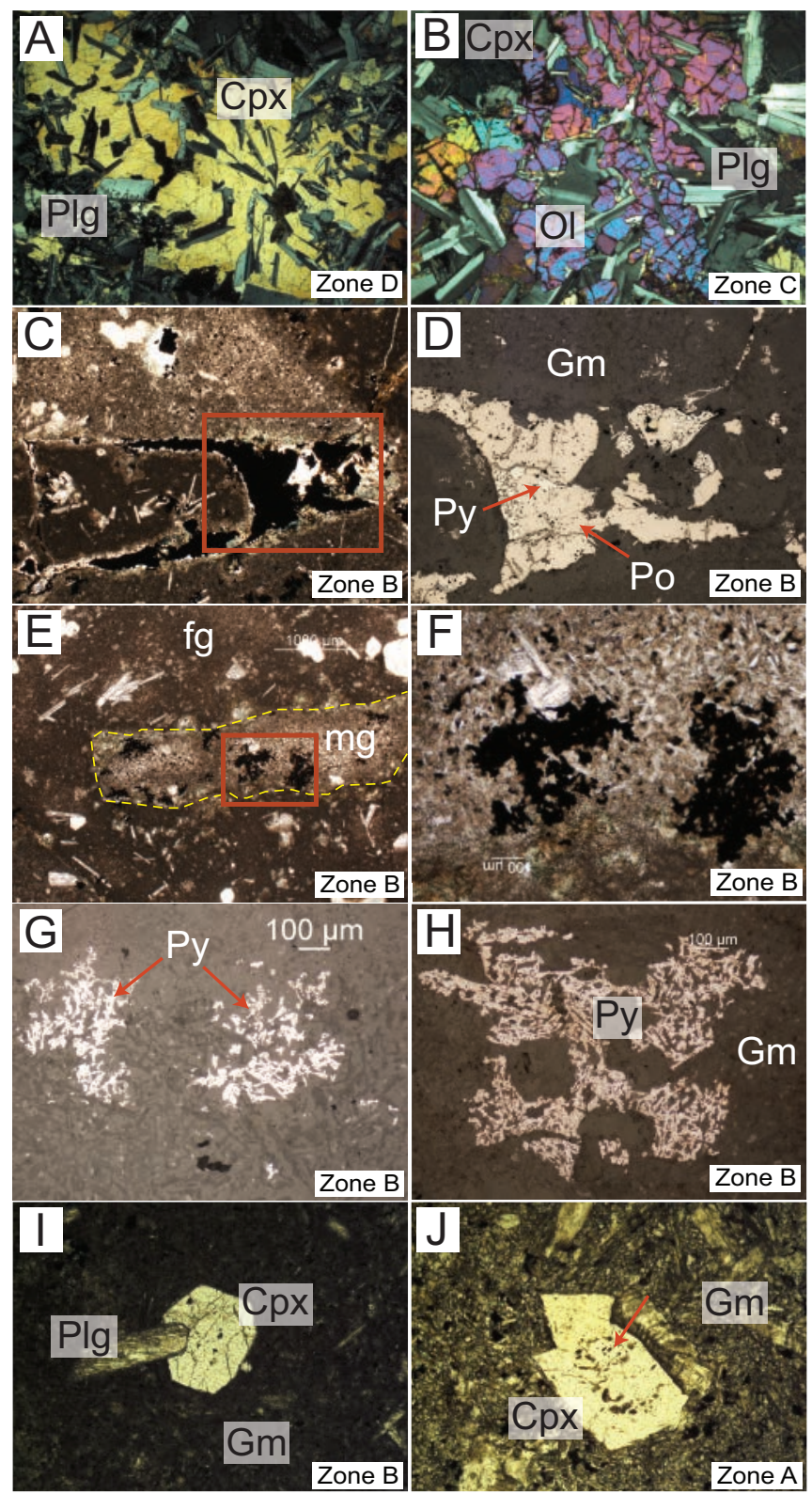

FIG. 10. Photomicrographs of minerals and textures from the Southern Feeder Dike Complex (FOV = field of view). A. Clinopyroxene $(\mathrm{Cpx})$ oikocryst enclosing plagioclase (Plg) chadacrysts (image in crossed polars, $\mathrm{FOV}=4 \mathrm{~mm}$ ) at Zone D. B. Interstitial olivine $(\mathrm{Ol})$ intergrown with plagioclase and clinopyroxene in the Zone $\mathrm{C}$ dike (image in crossed polars, FOV $=4 \mathrm{~mm})$. C. Plane-light image $(\mathrm{FOV}=2 \mathrm{~mm})$ of igneous sulfide trapped in a wedge-shaped pore in Zone B dike-propagator tip igneous breccia. D. Reflected-light image $(\mathrm{FOV}=1 \mathrm{~mm})$ of sulfide in red box from image $(\mathrm{C})$, which consists of pyrite (Py) and pyrrhotite (Po). E. Plane-light image (FOV $=1 \mathrm{~mm}$ ) of medium-grained diabase fragment in the Zone B dike propagator tip igneous breccia. Note that the diabasic microxenolith (outlined in dashed yellow line) is coarser than the quenched microphyric basalt in which it is embedded, suggesting it represents a wall-rock fragment and that it hosts several globular concentrations of sulfide. F. Plane-light image $(\mathrm{FOV}=1 \mathrm{~mm})$ and $(\mathrm{G})$ reflected-light image $(\mathrm{FOV}=1 \mathrm{~mm})$ close-ups of the two patches in lower center of the diabasic microxenolith shown in the red box in image (E). Note that sulfide impregnates the diabasic textured silicates. H. Another example of sulfide melt impregnation of microphyric diabase (reflected light, $\mathrm{FOV}=1 \mathrm{~mm}$ ). I. Clinopyroxene phenocryst intergrown with plagioclase in the microphyric basalt of the Zone B dike propagator tips (plane light, FOV $=1 \mathrm{~mm}$ ). J. Clinopyroxene phenocryst with spongy core (red arrows) hosted within groundmass at Zone A (plane light, FOV = $1 \mathrm{~mm}$ ). contain granular clinopyroxene and fine-grained, randomly oriented plagioclase laths. Small $(\sim 2-3 \mu \mathrm{m})$ euhedral grains of pentlandite, pyrrhotite and pyrite were observed within plagioclase crystals in some of these diabasic microxenoliths. Large $(\sim 200 \mu \mathrm{m})$ composite grains of pyrite and pyrrhotite were observed filling voids between microxenoliths (Fig. 10CD), suggesting that a sulfide melt was mobile during brecciation of the dikes. The diabasic microxenoliths also contain globular and patchy, net-textured sulfide (pyrite > pyrrhotite > > chalcopyrite) that appear to have impregnated the porous microdiabase prior to its incorporation into the next pulse of magma (Fig. 10E-H).

The Zone $\mathrm{E}$ dike displays very similar patterns to the dikes at Zones D and C, with a chilled margin that grades into medium-grained gabbro. Olivine in the chill is present as isolated phenocrysts, or as olivine glomerocrysts. The Kilian Formation directly at the dike margins at Zone $\mathrm{E}$ is brecciated, with fractures being filled with euhedral pyrite and calcite crystals (up to $1 \mathrm{~cm}$ in size), much as was observed in the brecciated Wynniatt Formation limestones at Zone B. Pyrite in these fractures appears to have been deposited in the permeable host rock breccia by hydrothermal fluids.

The Zone A dike contains very similar textures to those observed in the Zone $\mathrm{E}$ dike. However, there is an occurrence of a microporphyritic texture in a diabase from the gossanstained dike core (Fig. 4D) at Zone A, with microphenocrysts of plagioclase and clinopyroxene with sieve-textured cores (Fig. 10J), suggesting resorption. Sparse pyrite and chalcopyrite grains $(<1 \mathrm{~mm}$ in size) are present in the gossan-stained core region of the Zone A dike (Fig. 4D).

\section{Bulk-Rock Geochemistry}

The majority of gabbroic samples from the Southern Feeder Dike Complex have $\mathrm{MgO}$ contents $<10$ wt \%. Most gabbros show an $\mathrm{FeO}_{\text {(total) }}$ enrichment trend versus $\mathrm{MgO}$ (Fig. 11B), suggesting that melt evolution was controlled by the olivine + clinopyroxene + plagioclase cotectic. Most show L/HREE ratios typical of type-2 Franklin magmas (Fig. 11A). However, there are isolated occurrences of slightly more primitive ( 10-12 wt \% MgO) type-1 Franklin magma in the Complex (Fig. 11B). These occur in the dike propagator tips at Zone B and in the Zone $\mathrm{D}$ dike core.

Primitive mantle normalized multielement spidergrams show a general similarity of magmas emplaced in the Southern Feeder Dike Complex (Fig. 12). Enrichment of large ion lithophile elements (LILEs) and Pb suggest hydrothermal alteration of the rocks and remobilization of these elements (Fig. 12). There may be subtle differences between dike core and chilled margin compositions. For example, at Zone $\mathrm{D}$, the dike core is more enriched in incompatible trace elements than the dike chill (Fig. 12A). One sample from within the Zone D gabbroic roof apophysis shows higher L/HREE ratios than others, with values similar to the type-1 Franklin magmas (Fig. 12A). The gabbro from the sill-like body in the southwest region of Zone $\mathrm{D}$ is the most depleted in incompatible trace elements (Fig. 12A). The Zone C dike has a trace element pattern identical to the Zone D gabbros, while the dike chill at Zone $\mathrm{C}$ is most enriched (Fig. 12B). Zone B dike propagator tip trace element patterns are very similar to Zone $\mathrm{D}$ and $\mathrm{C}$ gabbros, indicating they are type-2 Franklin magmas 


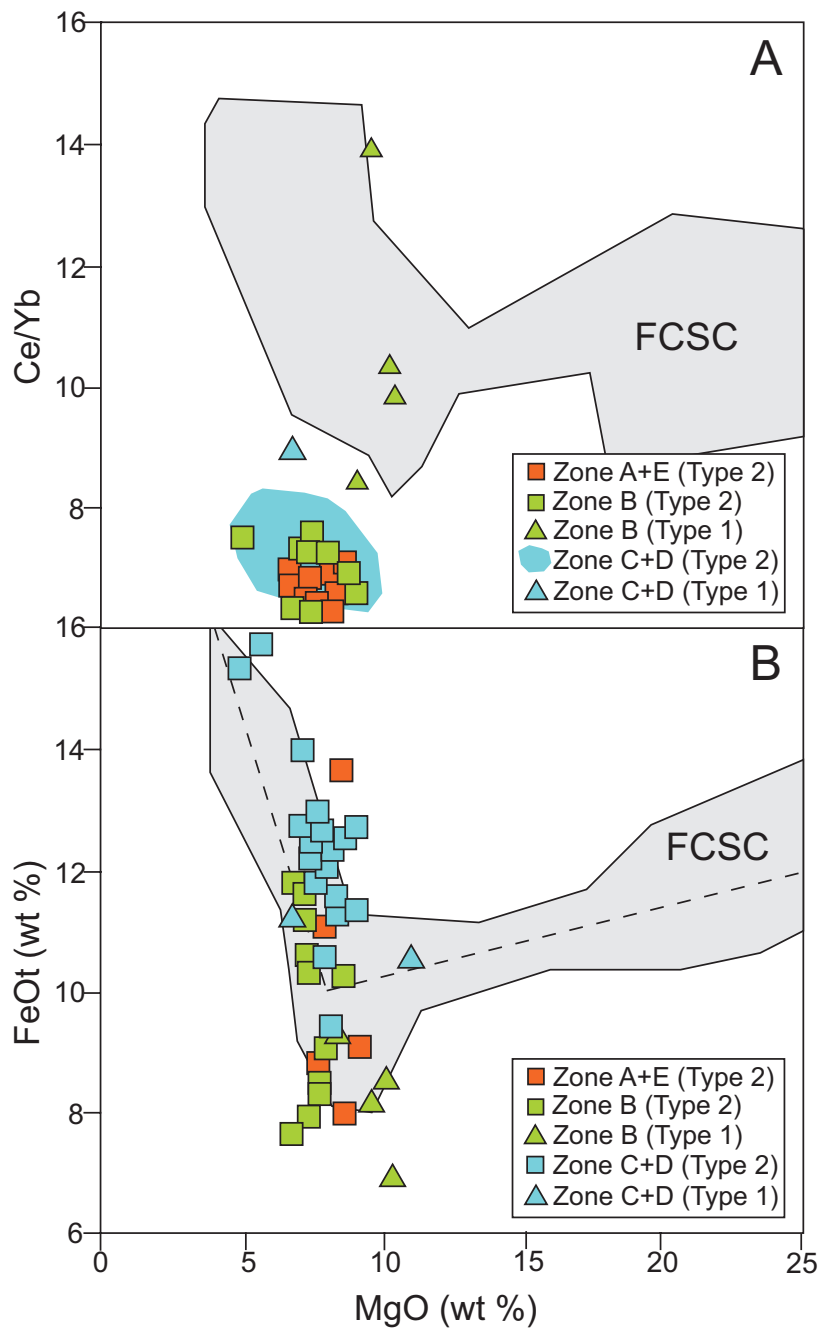

Fig. 11. A. Ce/Yb vs. MgO, showing Southern Feeder Dike Complex data.

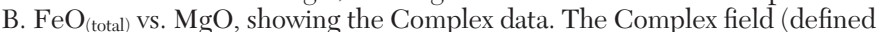
in Hayes et al., 2015b), which is composed of type-1 Franklin magma, is shown for reference in both plots.

(Fig. 12C). The LILEs and high-field strength elements (HFSEs) are notably more enriched in the Zone B propagator tips compared to Zones D and C (Fig. 12C). Dike rocks from Zones $\mathrm{A}$ and $\mathrm{E}$ are very similar to one another, indicating they formed from the same, or a very similar type-2 magma (Fig. $12 \mathrm{D}, \mathrm{E})$.

Chondrite-normalized PGE profiles from the Southern Feeder Dike Complex show that the gabbroic samples contain relatively low amounts of PGEs compared to chondrite abundances (Fig. 13A, B). The IPGEs are strongly depleted, suggesting either retention of Os-Ir alloys in the source or fractionation of minor chromite/alloys or olivine (Capobianco and Drake, 1990; Tredoux et al., 1995; Brenan et al., 2003) or in reduction fronts associated with chromite grain boundaries (Finnigan et al., 2008). Southern Feeder Dike Complex gabbros show a minor enrichment in $\mathrm{Pt}$ and $\mathrm{Pd}$, relative to other PGEs. Pt is particularly enriched in the dikes at Zones D and E (Fig. 13A).

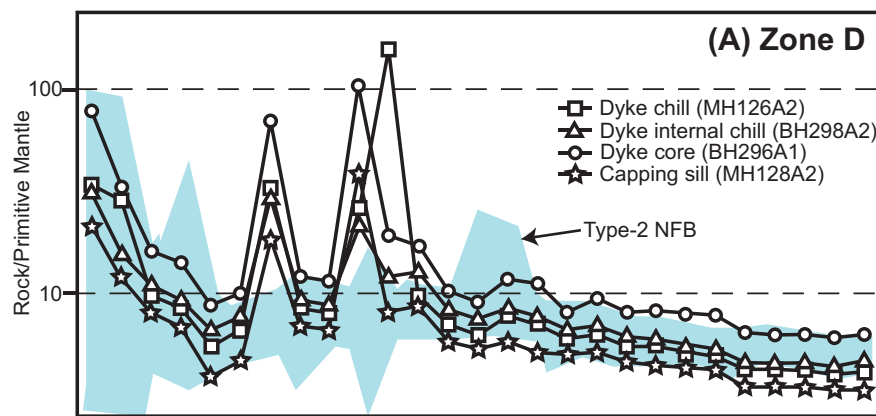

(B) Zone C
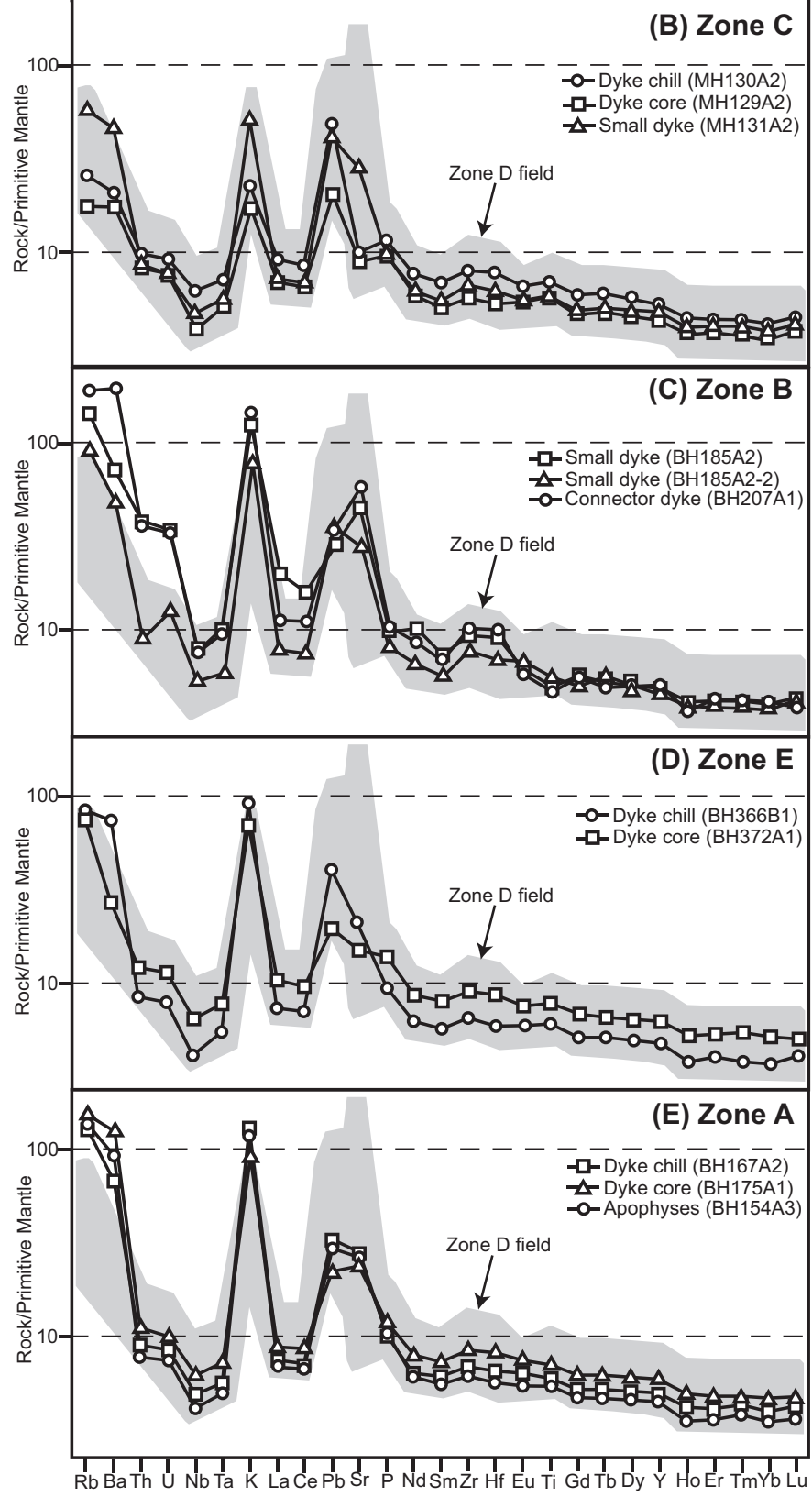

Fig. 12. Primitive mantle-normalized spidergrams, showing gabbroic samples from the Southern Feeder Dike Complex. A. Zone D, including in blue the type-2 Natkusiak flood basalts (NFB), which are very similar to Zone D gabbros. B. Zone C. C. Zone B. D. Zone E. E. Zone A, with the gray field in each showing the Zone $\mathrm{D}$ gabbros, for comparison. Normalizing values are from Sun and McDonough (1989). 


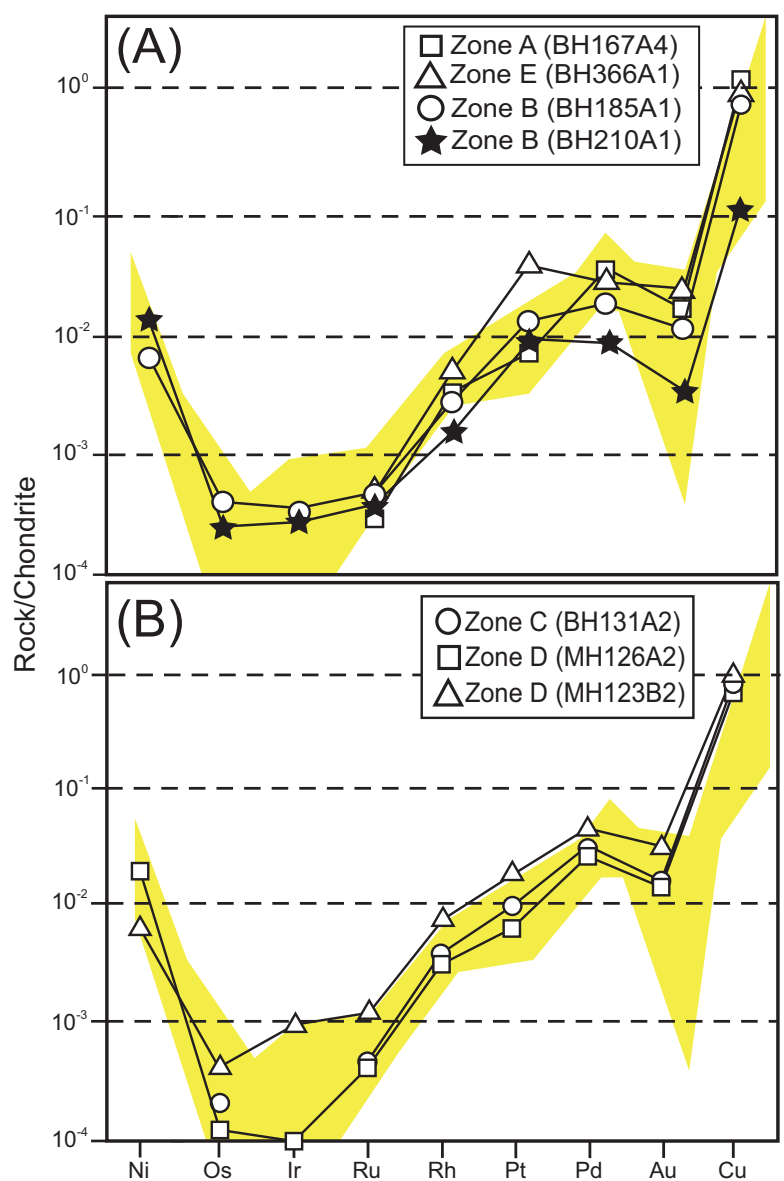

FIG. 13. Chondrite mantle-normalized PGE spidergrams, showing data from gabbroic samples from the Southern Feeder Dike Complex. A. Zones $\mathrm{A}, \mathrm{E}$, and B. B. Zones $\mathrm{C}$ and D. Normalizing values are from McDonough and Sun (1995). The yellow field shows PGE abundances in type-2 Natkusiak flood basalts $(n=45)$

\section{Sulfur Isotope Geochemistry}

The sulfur isotope data $\left(\delta^{34} S\right)$ for the Southern Feeder Dike Complex are presented in Figure 14 and Table 1. Samples are plotted and discussed from the bottom (NW) to the top (SE) of the stratigraphic order (Fig. 14) from Zones D, C, B, E to A. Gabbroic samples at Zone D have $\delta^{34} \mathrm{~S}$ values between 2.7 and $4.5 \%$. This is consistent with $\mathrm{S}$ isotope measurements from many Minto Inlier Franklin magmatic rocks, most of which have ${ }^{34} \mathrm{~S}$ values between 2 and 4 (Hryciuk et al., in prep.), possibly reflecting a mantle source that has slightly higher $\delta^{34} \mathrm{~S}$ values relative to primitive mantle. In contrast, Zone $\mathrm{C}$ gabbroic samples have more positive $\delta^{34} \mathrm{~S}$ values between 9.0 and $11.0 \%$. Similarly, the thin N- to NNEtrending dike propagator tips at Zone B have elevated $\delta^{34} \mathrm{~S}$ values between 4.8 and $12.7 \%$. These rocks also have higher sulfur contents (0.24-0.58 wt \%) than most igneous rocks in the Southern Feeder Dike Complex. At the top of the stratigraphy discussed here, the Zone $\mathrm{E}$ dike has $\delta^{34} \mathrm{~S}$ values of 9.7 to $10.4 \%$ and the Zone A dike has $\delta^{34} \mathrm{~S}$ values between $5.0 \%$ and $8.9 \%$, both also consistent with general upsection enrichment in ${ }^{34}$ S.

Sulfur isotope compositions of sulfide from Southern Feeder Dike Complex wall rocks are all enriched in ${ }^{34} \mathrm{~S}$, highlighting

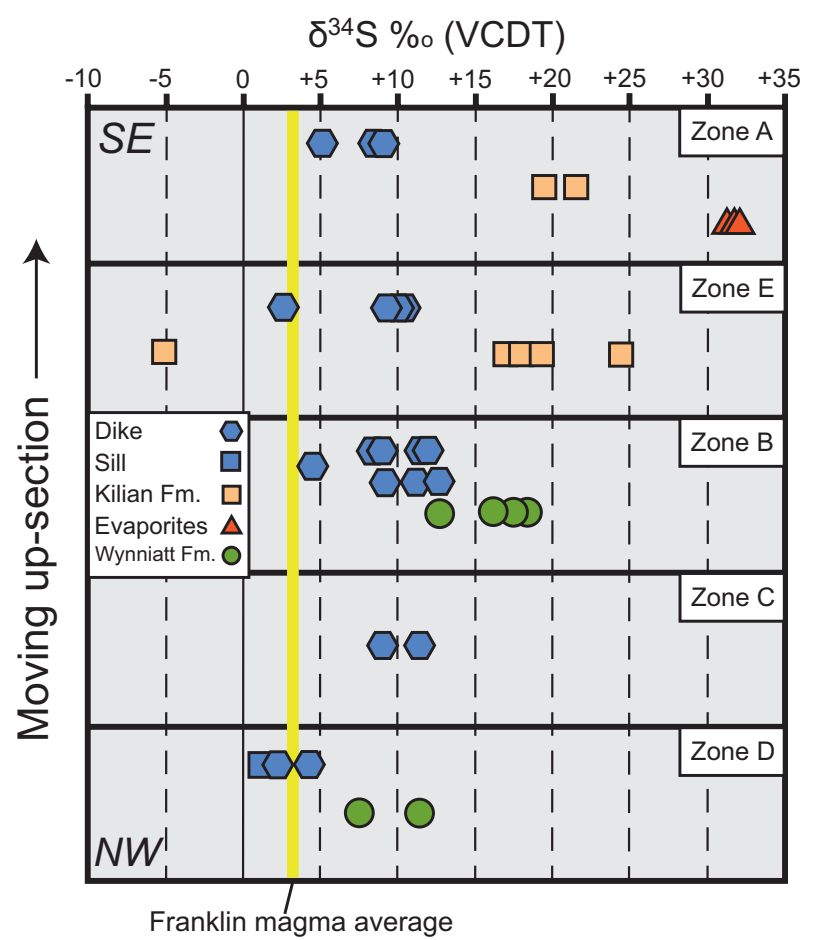

FIG. 14. $\delta^{34} \mathrm{~S}$ values (\%o VCDT) from dike, sill, and local country rocks across the Southern Feeder Dike Complex, in stratigraphic order.The evaporites at Zone A belong to the Kilian Formation. The vertical yellow line indicates the average $\delta^{34} \mathrm{~S}$ value of Franklin magmas (Hryciuk et al., in prep.). $\mathrm{Fm}=$ Formation .

potential sources for the magmatic $\mathrm{S}$ isotope trends identified here. Sulfides from the Wynniatt Formation limestone at Zone D have $\delta^{34} \mathrm{~S}$ values between 7.4 and $11.5 \%$, while at Zone B they have $\delta^{34} \mathrm{~S}$ values between 12.7 and $19.6 \%$. Sulfides from Kilian Formation carbonates at Zone B have $\delta^{34} \mathrm{~S}$ values between 17.0 to $24.0 \%$ and between 19.1 and $21.5 \%$ at Zone A. Kilian Formation sulfates are even more enriched in ${ }^{34} \mathrm{~S}$, with $\delta^{34} \mathrm{~S}$ values between 31.8 and $32.6 \%$. The Wynniatt and Kilian Formation sedimentary rocks hosting the Southern Feeder Dike Complex have elevated $\delta^{34} \mathrm{~S}$ values, typical of sedimentary rocks deposited in a basin with a restricted supply of sulfate and a significant microbial sulfur cycle (Prince, 2014).

In summary, magmatic rocks of the Southern Feeder Dike Complex show a general upsection ${ }^{34} \mathrm{~S}$ enrichment trend. The most positive magmatic $\delta^{34} \mathrm{~S}$ values occur in the dikes that are hosted by brecciated, sulfur-bearing country rocks in Zone B. Local sedimentary wall rocks throughout the Complex have elevated $\delta^{34} \mathrm{~S}$ values that also get more positive upsection.

\section{Anisotropy of Magnetic Susceptibility Fabrics}

Anisotropy of magnetic susceptibility was performed on 17 samples from the Southern Feeder Dike Complex to constrain magma flow directions (Table 2). Variation of susceptibility in cores of igneous rocks can be represented by a susceptibility ellipsoid, with maximum, intermediate, and minimum axes K1, K2 and K3, respectively (Ernst and Baragar, 1992; Tarling and Hrouda, 1993; Raposo and Ernesto, 1995; Glen et al., 1997; Palmer et al., 2007; Hastie 
et al., 2014). The plane of flattening of the ellipsoid is the $\mathrm{K} 1-\mathrm{K} 2$ plane, and the axis of elongation is the K1 axis. Studies of anisotropy of magnetic susceptibility in magnetitebearing rocks show the magnetofoliation, for convenience represented by the $\mathrm{K} 3$ axis, normal to the K1-K2 plane, and the magnetolineation, represented by the $\mathrm{K} 1$ axis, corresponds to the preferred shape orientation of multidomain magnetite (Borradaile and Henry, 1997). Thus the principal anisotropy of magnetic susceptibility axes, K3 and K1, in unstrained pristine igneous rocks is used as proxies for planes and lines of magmatic flow, respectively.

For the Southern Feeder Dike Complex, the mean magnetic susceptibility $(\mathrm{Km})$ is generally slightly higher and more variable for the sills $\left(5.25 \pm 2.6 \times 10^{-2}\right.$ SI: Fig. $\left.15 \mathrm{~B}, \mathrm{D}\right)$ than for the dikes $\left(3.38 \pm 1.4 \times 10^{-2}\right.$ SI: Fig. 15A, C). This is probably due to the more abundant and larger grain size of magnetite in the sills. The parameter $\mathrm{P}$, for the degree of anisotropy, is low, $<1.066$ for both sills and dikes, and is typical for fabrics of intrusive igneous rocks (Hrouda, 1982). The range of $\mathrm{P}$ is about the same for the sills as for the dikes. For both sills and dikes, the shape factor $\mathrm{U}$ suggests that prolate magnetofabrics
$(\mathrm{U}<0)$ are more common than oblate magnetofabrics $(\mathrm{U}>0)$, the ratio being about $1.4 / 1$, respectively (Fig. $15 \mathrm{C}, \mathrm{D}$ ).

In Figure $15 \mathrm{E}$ and $\mathrm{F}$, poles for the anisotropy of magnetic susceptibility axes are shown for dikes and sills, respectively. Squares represent poles of $\mathrm{K} 1$ axes and circles represent poles of $\mathrm{K} 3$ axes. The anisotropy of magnetic susceptibility axial distributions for the dikes is somewhat scattered, consistent with both variable dike orientation and variable flow patterns within dikes (Fig. 15E). In general, the K1 axes are better grouped than the $\mathrm{K} 3$ axes. The mean $\mathrm{K} 3$ of combined dike sites corresponds to a magnetofoliation striking $\mathrm{N} 33^{\circ} \mathrm{W}$ and dipping $73^{\circ} \mathrm{SW}$. The dike mean magnetolineation $\mathrm{K} 1$ in the plane of the magnetofoliation is steeply inclined to the SW at $72^{\circ}$ toward azimuth $237^{\circ}$. However, these are in situ orientations in the northern flank of a regional syncline (Fig. 1). Nearby to the west, the host Wynniatt Formation bedding strikes N $67^{\circ}$ $\mathrm{E}$ and dips $12^{\circ} \mathrm{SE}$. If dike emplacement preceded tilting of the bedding, as seems likely, then the present attitudes can be corrected for structural tilt, to estimate the original attitudes at the time of dike emplacement. Using the above estimate for tilt correction, the tilt-corrected orientation of the mean

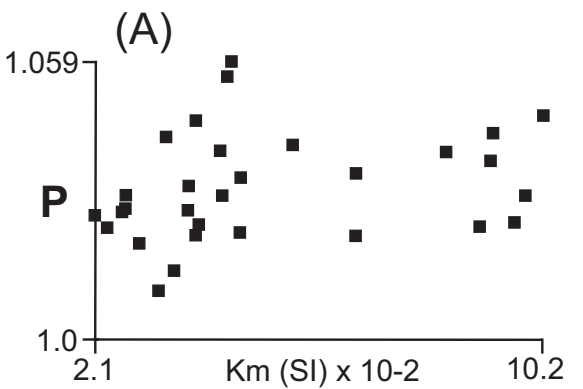

(B)
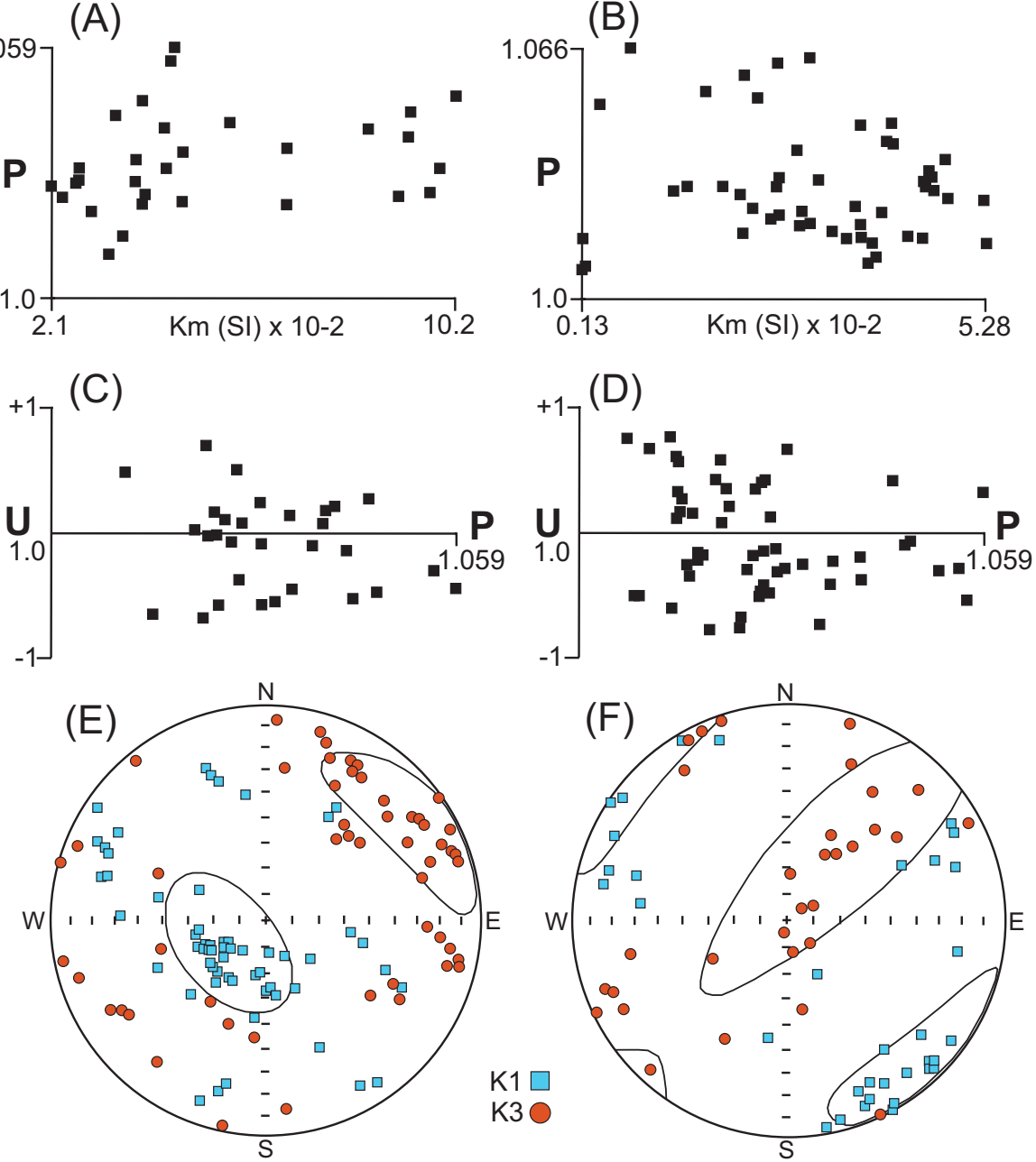

FIG. 15. Summary plots of magnetic susceptibility parameters for sills (A, C) and dikes (B, D) along the Southern Feeder Dike Complex. $\mathrm{P}=$ degree of anisotropy, $\mathrm{U}=$ shape parameter, and $\mathrm{Km}=$ mean sample susceptibility in S.I. units. Stereoprojection of anisotropy of magnetic susceptibility K1 axes (blue squares, maximum susceptibility) and of K3 axes (red circles, minimum susceptibility) for dikes (E) and sills (F) of the Complex; equal area, lower hemisphere projection. 
K1 axis for the dikes becomes approximately $65^{\circ}$ inclined toward azimuth $205^{\circ}$. This supports the interpretation that steep upward flow of magma during dike emplacement was from a southern source.

The anisotropy of magnetic susceptibility axial distributions for the sills (Fig. 15F) tends to be more streaked along greatcircle trends and less irregularly scattered than for the dikes. The mean magnetofoliation of combined sill sites, interpreted from the mean $\mathrm{K} 3$ axis, strikes $\mathrm{N} 55^{\circ} \mathrm{W}$ and dips $31^{\circ} \mathrm{SW}$, significantly steeper than typical sill-margin contacts. The sills sampled along the Southern Feeder Dike Complex exhibit mainly gently plunging $\mathrm{K} 1$ axes of northwest-southeast trend. This could be consistent with near-horizontal flow, but tectonic influences may also be involved. K1 axes are mainly well clustered at individual sill sites with larger scatter between sites. In deformed rocks, finite strain may affect anisotropy of magnetic susceptibility axial orientations (Borradaile and Henry, 1997). Combined magmatic-tectonic influences may produce streaked anisotropy of magnetic susceptibility axial patterns of primary and secondary (i.e., of magmatic and tectonic) origins. Such transitional magnetofabrics (Borradaile and Henry, 1997) could occur especially in the sill samples of the Southern Feeder Dike Complex.

\section{Discussion}

\section{The structure and emplacement of the} Southern Feeder Dike Complex

The Southern Feeder Dike Complex is located along a prominent regional NNW-trending first derivative magnetic lineament (Fig. 2B). These are widespread across the Minto Inlier and are interpreted to represent synmagmatic normal faults by Bédard et al. (2012). The Complex consists of NNWto NW-trending dikes and NE-SW-striking, SE-dipping sills (Fig. 2A). In many cases, host rocks show evidence of brecciation (Fig. 4B), and at Zone B, previously brecciated and hydrothermally altered dike material was reinjected by fresh dikes. This implies synmagmatic faulting, as well as the reactivation of previously used magma conduits. In many places, drag folds indicating fault shear sense are preserved in the host rocks, which may be due to the rheologically weak country-rock carbonates that soften markedly during magma emplacement (Žák et al., 2012). At Zones D and C (Figs. 3, 6), meter-scale drag folds indicate east-side-down motion on an NE-dipping normal fault. The softening of the country rock implies significant heat loss from the dikes, which could have driven hydrothermal cells in fault damage zones surrounding the Southern Feeder Dike Complex.

Zone D is the stratigraphically deepest part of the Southern Feeder Dike Complex. It preserves a 20-m-thick dike-like gabbroic roof apophysis ("a," Fig. 3) that injected a parasitic fault in the downdropped hanging-wall limestone panel (Fig. 5). The edge of the main gabbroic mass may also have been a dike ("b," Fig. 3), with the contact subsequently being sharpened by faulting. These synfaulting dikes probably fed the capping sill, which extends for tens of kilometers toward the southwest, but no direct linkage between the sill and the dike-like facies is observed. However, interlayered calc-silicate and $\mathrm{Fe}$ oxide exoskarn rocks occur in the inferred contact region. The calc-silicates in the skarn suggest intense contact metamorphism during sill emplacement (Nabelek et al., 2013). The Fe oxide facies of the skarn was inferred to represent the expulsion of late Fe-rich magmatic fluids from the sills into the roof panel limestones at the Uhuk Massif (Bédard et al., 2012; Nabelek et al., 2013). If the analogy with the field relationships at the Uhuk Massif holds, then the skarn facies at Zone D would be remnants of a metamorphic aureole that sheathed the conduit system that fed the Zone D sill. This is consistent with the idea that the carbonate and discrete dike ("a," Fig. 3) that composes most of Zone D is a downdropped hanging-wall panel, and that the dike-like feeder of the sill located near the gabbro/limestone contact ("b," Fig. 3) was partly faulted out. The proximity of the Zone C dike to Zone $\mathrm{D}$, together with its similar size and orientation, suggests it is an extension to a higher stratigraphic level of the Zone D feeder dike. This is consistent with anisotropy of magnetic susceptibility data that indicate dominant upflow in the dikes (Fig. 15). At the present erosional level, the Southern Feeder Dike Complex is segmented, but the dikes constituting this system may be connected at depth, as is typical of many dike systems (Delaney and Pollard, 1981; Rivalta et al., 2015).

We infer that the NNW- to NW-trending rubbly gabbro at the northeast end of Zone B is also an upsection continuation of the Zones D and C feeder dike. However, Zone B also has numerous thinner $(\sim 0.5-2 \mathrm{~m}) \mathrm{N}$ - to NNE-trending dikes that splayed off from the main fault-guided dike (Fig. 7). The orientation of the thinner N- to NNE-trending dikes suggests injection of magma into a conjugate fracture system. The sulfide-bearing igneous breccias in the thin dikes are cemented by microphyric basalt, confirming the synfaulting nature of magmatism. The overprinting hydrothermal system generated by dike intrusion appears to have remobilized sulfides and deposited them in the surrounding, permeable limestone breccia, making them available for assimilation by later melt pulses. We interpret the thinner dikes at Zone B to be propagator tips emplaced into an active fault.

Zones $\mathrm{E}$ and A consist of a single, discrete, NNW- to NWtrending dike emplaced into sulfates and carbonates of the Kilian Formation. This is the stratigraphically highest region of the Southern Feeder Dike Complex. No dikes are present above this level at this location, suggesting that the dikes may have fed the overlying sills (Fig. 4D). At both Zones E and A (Figs. 8, 9), southwest-side-down motion on a normal fault is preserved, the opposite of that seen at Zones D and C. This suggests that the Complex fault system has a horst and graben geometry (as shown in Fig. 5) and is composed of numerous, synchronously active fault strands, many of which were exploited by Franklin magmas. Lateral dike propagation at deeper crustal levels may have induced the formation of this horst and graben geometry, as previously proposed for NNWtrending faults within the Minto Inlier (Aspler and Ernst, 2003). On the other hand, the striking regional-scale linearity of the NNW-trending lineaments suggests that it reflects a dominant southwest-northeast extensional stress field.

\section{Evidence for a composite magmatic system}

The presence of internal chills within the dike-like roof apophysis at Zone $\mathrm{D}$, and the presence of igneous breccias at Zone B (Figs. 4C, 10E, F), implies that the Southern Feeder Dike Complex was a composite magmatic system. 
Sieve-textured clinopyroxene phenocrysts indicate resorption caused by magmatic replenishment in the plumbing system. Geochemically, the Complex is mostly composed of relatively fractionated type-2 Franklin magma (Fig. 11A). However, there are isolated occurrences of more primitive type-1 magma at Zones D and B (Fig. 11A). The presence of both populations of Franklin magma suggests that the Complex acted as a conduit system for the first (type-1 magma) stage of Franklin LIP magmatic activity, and that this older conduit system was then reactivated and flooded by type- 2 magma during the main basaltic effusion stage. Anisotropy of magnetic susceptibility fabrics in the dikes shows steep upflow fabrics indicating that magma ascended from depth through dikes. The apparent northerly magma flow direction measured in the Complex may be a local effect caused by the channeling of Franklin magmas through a complex underlying plumbing system.

Sulfur isotope and textural evidence for sulfide immiscibility in the Southern Feeder Dike Complex triggered by crustal assimilation

Various mechanisms for sulfur saturation in mafic magmas have been proposed: (1) fractional crystallization (Czamanske and Moore, 1977; Wendlandt, 1982), (2) changing $f_{\mathrm{O}_{2}}$ conditions (Haughton et al., 1974), (3) magma mixing (Irvine, 1975; Scoates and Mitchell, 2000), and (4) addition of external crustal sulfur (Ripley et al., 2003; Keays and Lightfoot, 2010). The assimilation of crustal sulfur into magma is a particularly potent way to trigger formation of an immiscible sulfide liquid. Although some Fe-Ni-Cu deposits, such as Jinchuan in China (Ripley et al., 2005; Lehmann et al., 2007) and NeboBabel in Australia (Seat et al., 2009), do not show isotopic evidence for the involvement of external sulfur, $\delta^{34} \mathrm{~S}$ data from the Southern Feeder Dike Complex imply that some Franklin magmas interacted with, and may have assimilated, their local country rock (Fig. 14).

Large positive $\delta^{34} \mathrm{~S}$ values in mafic rocks are typically interpreted as evidence of the incorporation of crustal sulfur ( $\mathrm{Li}$ et al., 2009), because magmas from the primitive mantle have $\delta^{34} \mathrm{~S}$ values of $\sim 0 \%$ (Labidi et al., 2014), while sedimentary sulfides and sulfates can have large positive $\delta^{34} \mathrm{~S}$ values. The majority of Franklin magmatic rocks have $\delta^{34} \mathrm{~S}$ values that are slightly higher than primitive mantle, typically between 2 and $4 \%$ (Hryciuk et al., in prep.). Xenoliths from the subcontinental lithospheric mantle (SCLM) contain sulfides that are, on average, ${ }^{34} \mathrm{~S}$ enriched relative to primitive mantle (Giuliani et al., 2014). The slightly positive $\delta^{34} \mathrm{~S}$ values of most Franklin magmatic rocks point to, but do not prove, a role for the SCLM in Franklin magmatism. Although their ultimate origin is not completely understood, the $\delta^{34} \mathrm{~S}$ values of typical Franklin magmatic rocks can provide a robust baseline for monitoring the addition of crustal sulfur.

The $\delta^{34} \mathrm{~S}$ values of the gabbros at Zone $\mathrm{D}$ are similar to typical Franklin magmatic values and therefore, within this framework, preserve no sulfur isotopic evidence of contamination by sedimentary sulfur. Slightly upsection at Zone C, $\delta{ }^{34} \mathrm{~S}$ values increase to $\approx 10 \%$, consistent with assimilation of sulfur from ${ }^{34} \mathrm{~S}$-enriched sediments. Likewise, the dike propagator tips at Zone $\mathrm{B}$ also have large positive $\delta^{34} \mathrm{~S}$ values that extend to nearly $13 \%$, while the $\delta^{34} \mathrm{~S}$ values of sulfides from the Zone A dike (up to $9 \%$ ) and the Zone E dike ( $\approx 10 \%$ ) are large and positive as well. This sulfur isotope trend in the magmatic rocks broadly mimics the upsection "bloom" in $\delta^{34} \mathrm{~S}$ values seen in the host country rocks (Fig. 14), suggesting that local incorporation of sedimentary sulfur into through-flowing magma may have been responsible for the elevated $\delta^{34} \mathrm{~S}$ values in the magmatic sulfides.

Supporting evidence from the Southern Feeder Dike Complex strengthens this suggestion. The $\delta^{34} \mathrm{~S}$ values from the propagator tips at Zone B trend toward the sulfur isotope composition of sulfides in their host country rock (Fig. 14), pointing toward a local sulfur contaminant. In addition, hydrothermally altered and sulfur-depleted country rock occurs in proximity to the Zone $\mathrm{E}$ dike, highlighting the possible assimilatory role of sulfur liberated by metamorphic devolatilization reactions (Hryciuk et al., in prep.). Finally, even the most elevated $\delta^{34} \mathrm{~S}$ values observed in the Complex are consistent with admixing small amounts of sedimentary sulfur. For example, if an uncontaminated magma has $620 \mathrm{ppm}$ sulfur and $\delta^{34} \mathrm{~S}$ of $3.6 \%$ (taken as the average $\delta^{34} \mathrm{~S}$ value of Franklin magma), then assimilation of $\approx 0.05 \%$ anhydrite by mass with a $\delta^{34} \mathrm{~S}$ value of $32 \%$ can explain $\delta^{34} \mathrm{~S}$ values greater than $8 \%$ (Ripley and Li, 2003).

Such local sulfur assimilation was apparently enough to trigger sulfide saturation. The sulfur contents of the Zone B dike propagator tips (up to 0.58 wt \%: Table 1 ) are greater than the 0.14 wt \% S required for sulfide saturation in typical basaltic magmas (Jugo et al., 2005), while the diabasic microxenoliths within the dike propagator tips at Zone B host direct evidence of magmatic sulfide immiscibility (Fig. 10E-H). These sulfide globules show that immiscible sulfide liquid impregnated a porous microdiabasic crystal mush (Fig. 10C-H). The sulfideimpregnated diabasic microxenoliths were then reworked and brecciated by the next magma pulse. It is possible that the injecting basaltic melt that now cements the fine-grained diabasic microxenoliths could have scavenged and ingested sulfide hosted within the microxenoliths, in addition to incorporating external crustal-derived sulfur directly, thus enhancing the downstream ore-forming potential of the Southern Feeder Dike Complex.

\section{Tectonic and structural characteristics of the Southern Feeder Dike Complex and their role in the formation of immiscible sulfide liquids}

Many studies of Fe-Ni-Cu deposits have focused on petrological and geochemical aspects, with less attention paid to the morphology of magma chambers and conduits that form intrusions and which host sulfides (Ripley and Li, 2011; Lightfoot and Evans-Lamswood, 2015). An additional factor that may be important for their genesis is the tectonic setting of the deposit. $\mathrm{Fe}-\mathrm{Ni}-\mathrm{Cu}$ deposits are typically associated with magma plumbing systems that are located near cratonic margins (Begg et al., 2010). Craton margins may act as favorable sites for the ascent and emplacement of significant quantities of primitive Ni-rich magmas, which can then interact with crustal rocks at shallower levels (Begg et al., 2010; Lightfoot and Evans-Lamswood, 2015). The Franklin LIP exposed in the Minto Inlier is close to the northwestern margin of the Slave craton. Therefore, primitive Franklin magmas sourced from the mantle may have been focused by the craton's 
thinned edge during break-up of Rodinia. Additionally, Franklin intrusions on Victoria Island are relatively close to the inferred source of the Franklin LIP (Fig. 1), near Banks Island (Ernst and Jowitt, 2013).

Regional extension associated with the emplacement of Franklin magmas (Rainbird, 1993) would generate normal fault systems, facilitating the emplacement of Franklin magmas (Bédard et al., 2012). The fault-controlled Southern Feeder Dike Complex has morphological characteristics similar to those observed in well-documented $\mathrm{Fe}-\mathrm{Ni}$-Cu deposits, such as Noril'sk and Voisey's Bay (Lightfoot and Evans-Lamswood, 2015). For instance, intrusions at most $\mathrm{Fe}-\mathrm{Ni}-\mathrm{Cu}$ deposits have morphologies that are thought to be controlled by preexisting and reactivated structures in the crust, which guided primitive, mantle-derived magmas upsection (Lightfoot and Evans-Lamswood, 2015; Saumur et al., 2015). At both Voisey's Bay and Jinchuan, it is presumed that synmagmatic faulting enabled the emplacement of magmas ( $\mathrm{Li}$ et al., 2004; Lightfoot and Evans-Lamswood, 2015). However, magma emplacement relationships at Jinchuan are unclear because of deformation associated with faulting (Lightfoot and Evans-Lamswood, 2015). At the Southern Feeder Dike Complex, we see evidence that synmagmatic normal faults facilitated and guided the emplacement of Franklin magmas. Additionally, the interplay between faulting, magmatism, and wall-rock assimilation is preserved. It is generally accepted that sulfur saturation is required in the associated magmatic plumbing of an $\mathrm{Fe}-\mathrm{Ni}-\mathrm{Cu}$ deposit during its evolution (Keays and Lightfoot, 2010). The field evidence preserved at the Complex records how external, crustal-derived sulfur may be added to magma, leading to locally triggered sulfur saturation and the formation of immiscible sulfide liquids.

\section{Implications for the generation of conduit-type $\mathrm{Fe}$-Ni-Cu deposits}

There is an ongoing debate about how and where magma becomes sulfursaturated within the magmatic plumbing systems of Fe-Ni-Cu deposits (Naldrett, 1992; Ripley et al., 2003; Ripley and Li, 2013). The dike-fault relationships of the Southern Feeder Dike Complex share many similarities to conduit-type ore deposits such as Noril'sk (Naldrett, 1992; $\mathrm{Li}$ et al., 2009), Voisey's Bay (Li et al., 2000), and the Eagle deposit (Ding et al., 2012), where it has been inferred that faulting associated with rifting facilitated ore genesis, and that the ingestion of sulfate-bearing country rocks into a PGEenriched magma generated the orebodies (Li et al., 2009). The latter inference is supported by the heavy $\delta^{34} \mathrm{~S}$ composition of the magma, which is higher than mantle-like values and trends toward the $\delta^{34} \mathrm{~S}$ composition of the surrounding sulfate-bearing country rocks (Grinenko, 1985). However, the actual mechanism for ingestion of sulfur-rich country rock into the Noril'sk magma is unclear (Ripley et al., 2003). Naldrett (1999) proposed that thermal erosion of the magma chamber walls during multiple magmatic pulses led to the ingestion of Devonian evaporites and carbon-bearing country rocks at Noril'sk. In the Southern Feeder Dike Complex, the country rock is brecciated as a result of Neoproterozoic faulting. Emplacement of magma into fault zones could allow more extensive interaction because of the increased surface area provided by the brecciated country rock. At Zone B in particular, the dike propagator tips intrude S-bearing brecciated carbonates and older brecciated dike material (Fig. 4C). The $\delta^{34} \mathrm{~S}$ values of the Zone B propagator tips are especially high (up to 13\%o) and trend toward $\delta^{34} \mathrm{~S}$ values of the surrounding country rock (Fig. 14).

In summary, the Southern Feeder Dike Complex represents a fossilized magmatic feeder system that was emplaced into an active normal fault system, near the margin of the Slave craton and proximal to the inferred plume source (Ernst and Jowitt, 2013). Our data imply that crustal sulfur was ingested by the magma, triggering local sulfur saturation and the formation of immiscible sulfide liquids. Brecciation associated with this faulting may have facilitated the assimilation of host sulfur, both by increasing available reactant surface area, and more speculatively, by preconcentrating $\mathrm{S}$ and $\mathrm{Cu}$ through forced hydrothermal circulation in high-permeability fault breccias and surrounding fault damage zones (Caine et al., 1996; Evans et al., 1997). Wall-rock assimilation by fault-related brecciation is indeed an efficient mechanism at triggering sulfur saturation in basaltic magma (Robertson et al., 2015). Similar mechanisms may have been involved in forming $\mathrm{Fe}-\mathrm{Ni}-\mathrm{Cu}$ orebodies in other conduit-type magmatic systems where direct physical evidence for wall-rock assimilation was obliterated by sustained magma throughflow (Naldrett, 1992; Lightfoot and Evans-Lamswood, 2015). The dike propagator tips at Zone B appear to represent magmatic dead ends where rapid cooling limited the upgrading process. Conversely, this is why textural evidence for immiscible sulfide generation has been preserved there. At Zone B, sulfide immiscibility caused by wall-rock assimilation appears to have been "caught in the act." The Southern Feeder Dike Complex provides a snapshot of the mechanisms of crustal sulfur addition during fault-controlled mafic magma emplacement, thus informing ore-forming models proposed for conduit-type $\mathrm{Fe}$ $\mathrm{Ni}-\mathrm{Cu}$ deposits elsewhere.

\section{The economic Fe-Ni-Cu potential of the Southern Feeder Dike Complex and the Franklin LIP}

The synfaulting scenario for magma emplacement and contamination documented in the Southern Feeder Dike Complex and the Uhuk Massif (Bédard et al., 2012) may also apply to the entire Franklin magmatic plumbing system in the Minto Inlier. The evidence from the Zone B propagator tips is particularly compelling, because the processes that appear to have operated there (magma emplacement, contamination, sulfide immiscibility) may represent the early stages in the genesis of an $\mathrm{Fe}-\mathrm{Ni}$-Cu deposit. Additionally, the evidence from Zone B may be applicable to the entire Complex during its emplacement, given the elevated $\delta^{34} \mathrm{~S}$ values recorded in other parts of the system (Fig. 14). NNW- to NW-trending magnetic lineaments are found throughout the Minto Inlier (Kiss and Oneschuk, 2010), and each may represent a potential synfaulting dike that could have transported significant quantities of magma upsection. In these synmagmatic fault systems, where brecciation and cataclasis increase reactant surface areas, flowing magma could have ingested crustal sulfur, triggering the formation of immiscible sulfide liquids. This is the scenario that appears to be preserved at Zone B. The intersections of these synmagmatic faults with sulfate-rich sediments of the Kilian and Minto Inlet Formations would appear to be 
particularly promising exploration targets. Such fault systems could also be favorable sites for the emplacement of subsequent magma pulses, generating composite magma systems with the capacity to upgrade the tenor of early sulfides. Where the magma systems are better developed, as at Zone $\mathrm{D}$, prior evidence of contamination (if it indeed occurred) would have been flushed downstream.

The evidence that sulfide immiscibility occurred in Zone $B$ raises the question of where any possible immiscible sulfide liquids were deposited. A hydraulic trap is required in order to produce economically viable quantities of immiscible sulfide liquids (Naldrett, 1992). Localization of sulfide mineralization tends to be related to changes in the geometry of the magma plumbing system, such as a hydraulic jump from a dike to a sill (Lightfoot and Evans-Lamswood, 2015; Saumur et al., 2015). Therefore, the most probable targets in the Franklin LIP would be the downstream extensions of sills that were fed by Southern Feeder Dike Complex dikes, similar to what has been inferred for Voisey's Bay (Lightfoot and Evans-Lamswood, 2015). Approximately $10 \mathrm{~km}$ southwest of the capping sill at Zone A, there are dikes containing unusual amounts of sulfide ( $5 \%$, Sulfide City Dike, "SCD," Fig. 1) with small semimassive sulfide concentrations at their contacts. Contact sulfide pods contain on average, 16.7 wt \% $\mathrm{S}, 106 \mathrm{ppm} \mathrm{Ni}$, and 4,469 ppm Cu (unpub. data). At the same horizon, large calcite- and pyrite-rich gossans are associated with a sill (Gossan sill: Fig. 16A, "GS," Fig. 1, and see Peterson et al., 2014). Although sulfides at the Gossan Sill appear to be mainly hydrothermal in origin (Fig. 16B), it is possible that some of it was scavenged from immiscible sulfide previously concentrated in one of the adjoining sills.

In addition to the dike-fault systems acting as dynamic environments, the occurrence of type-1 magma in the Southern Feeder Dike Complex is significant (Fig. 11A). Type-1 magmas were emplaced first in the Franklin LIP and are commonly found deeper in the Shaler Supergroup. Type-1 chills (e.g. frozen liquids) are often primitive (up to $\sim 13 \mathrm{wt}$ $\% \mathrm{MgO}$ ) with high $\mathrm{Ni}$ contents up to $~ 560 \mathrm{ppm}$. Type-1 Franklin magmas were hotter $\left(\sim 1,300^{\circ} \mathrm{C}\right)$ than type-2 Franklin magmas, and therefore would have had more potential to reactivate S-rich crustal rocks. The Uhuk Massif was inferred to be the major melt and crystal slurry feeder to the type-1 olivine-enriched Fort Collinson Sill Complex (Hayes et al., 2015b). Pulses of magma and crystal slurries may have waxed and waned during episodic fault slip and upstream sill collapse during melt evacuation at the Uhuk Massif. It has been proposed that melt evacuation triggered by sill collapse played a role in the generation of the Voisey's Bay $\mathrm{Fe}-\mathrm{Ni}$ $\mathrm{Cu}$ deposit (Cruden et al., 2008). There is also evidence for magmatic replenishment and magma mixing in sills associated with type-1 magmas (Naslund et al., 2013; Hayes et al., 2015a), which can act as an additional mechanism for triggering sulfur saturation (Irvine, 1975; Scoates and Mitchell, 2000). Later type-2 magma pulses that utilized the Southern Feeder Dike Complex may have ingested earlier sulfides associated with type-1 magmas. The association of type-1 magmas in the Complex, as well as other dike feeder systems in the Minto Inlier, therefore enhances the $\mathrm{Fe}-\mathrm{Ni}-\mathrm{Cu}$ economic potential of the Franklin LIP and further investigation is required.
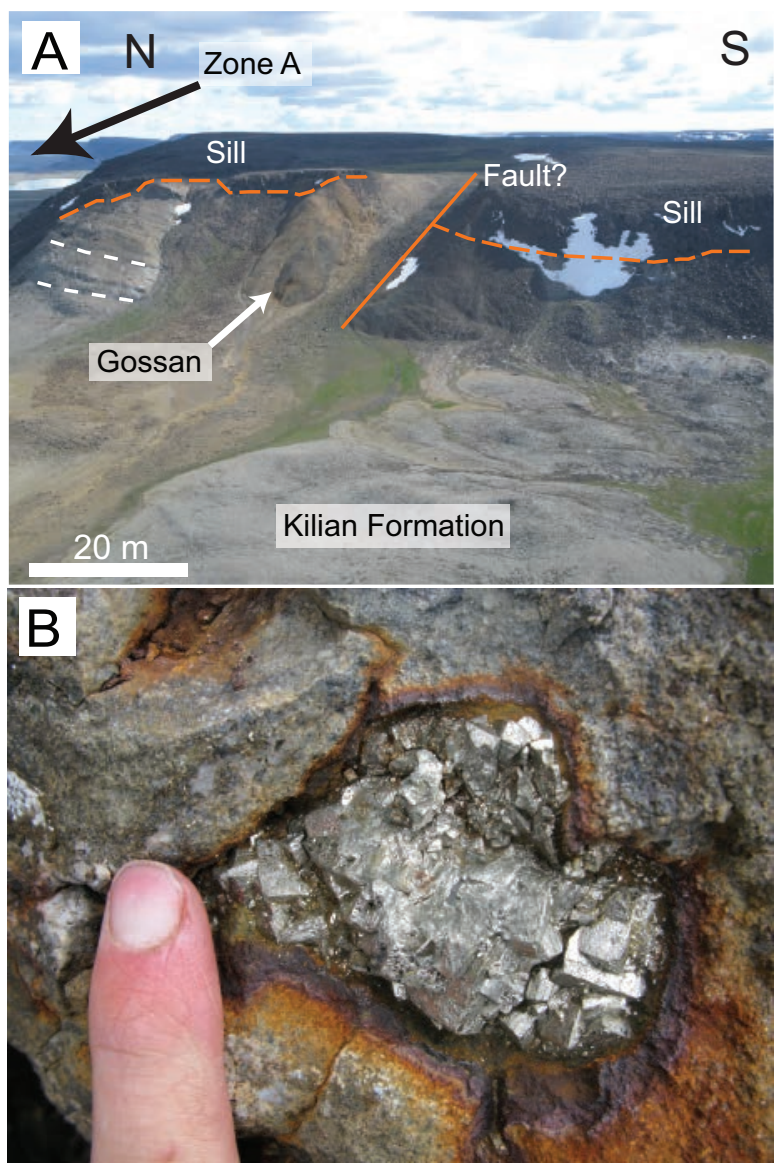

FIG. 16. A. Field photo of the Gossan sill (GS) situated $\sim 10 \mathrm{~km}$ westsouthwest of the Southern Feeder Dike Complex. The dashed red line shows the sill contact with the Kilian Formation country rocks (dashed white lines for bedding). B. Hydrothermal pyrite globules with oxidized halos in the Kilian Formation just below the contact with the sill.

\section{Conclusions}

The Southern Feeder Dike Complex on Victoria Island in the Canadian Arctic is part of the Franklin LIP, which extends across northern Canada and into Greenland. The part of the Franklin LIP exposed on Victoria Island is primarily composed of gabbroic sills, with subordinate NNW- to NW-trending feeder dikes. Igneous breccias cemented by basalt and drag folds within wall rocks indicate that Franklin magmas were emplaced contemporaneously with regional Neoproterozoic normal faulting. The Complex dikes acted as dynamic magma conduits that facilitated the ingestion of crustal sulfur into the magma, which we believe triggered the formation of immiscible sulfide liquids. This scenario is supported by heavy $\delta^{34} \mathrm{~S}$ values of the dikes. There are sulfide showings associated with Franklin sills and dikes across the Minto Inlier, including the Complex area. Globular and locally net-textured sulfides are associated with diabasic microxenoliths that were cemented by later basaltic magmas, indicating that sulfide immiscibility was coeval with dike emplacement and faulting. Evidence that the Complex was a composite magmatic system suggests that previously formed immiscible sulfide liquids may have been ingested by fresh magma. In the more robust part of the Complex where dikes and sills are well developed, the evidence for 
sulfide immiscibility may have been flushed downstream. The Complex appears to feed laterally extensive sills at different crustal levels. These sills may represent hydraulic traps that could have concentrated immiscible sulfide liquids. There are gossan showings in the sills downstream from the Complex, which may represent late hydrothermal reworking of such sulfides. Similar processes of wall rock-induced sulfide immiscibility may have operated in dike-feeder systems across the Franklin LIP in the Minto Inlier, suggesting that the Franklin igneous rocks on Victoria Island are indeed prospective for Fe-Ni-Cu deposits. The textures and field relationships documented in the Southern Feeder Dike Complex support models where sulfide immiscibility is triggered by sedimentary wall-rock assimilation during fault-guided magmatic activity and have implications for the genesis of $\mathrm{Fe}-\mathrm{Ni}-\mathrm{Cu}$ deposits in conduit-type magmatic systems.

\section{Acknowledgments}

This study was a part of the Geomapping for Energy and Minerals (GEM) program, orchestrated by the Geological Survey of Canada. We would like to thank the field crew of the Victoria Island mapping expedition, who contributed to two successful mapping field seasons. We particularly extend thanks to the helicopter pilots for safe taxi rides back and forth to the Southern Feeder Dike Complex and the people of Ulukhaktok for their welcome. Étienne Girard and Fannie Lessard provided invaluable assistance with the digital mapmaking process. Iain McDonald, Ley Wooley, Thi Hao Bui, and Marc Choquette are thanked for their help in the laboratories. Comments by Wolfgang Maier, Michel Houlé, and Robert Knight were valuable. We are grateful to Larry Meinert, Richard Ernst, and Paul Golightly for their constructive reviews, which significantly improved the manuscript. The Stable Isotope Laboratory at McGill is supported by an NSERC Discovery grant to Wing and by the FQRNT through the GEOTOP research center. Hryciuk was supported by a Gold Fields SEG Foundation Graduate Student Fellowship, a Natural Sciences and Engineering Research Council (NSERC) CGS-M scholarship, and a Natural Resources Canada Research Affiliate Program Bursary. Hayes was supported by a Natural Environment Research Centre (NERC) research studentship (grant NE/152787X/1). This is NRCAN/ ESS contribution no. 20140542.

\section{REFERENCES}

Arndt, N.T., 2011, Insights into the geologic setting and origin of Ni-Cu-PGE sulfide deposits of the Noril'sk-Talnakh region, Siberia: Reviews in Economic Geology, v. 17, p. 199-215.

Aspler, L.B., and Ernst, R.E., 2003, Dyke-induced graben on Venus and Mars: Analogues for Earth's rock record [ext. abs.]: Lunar and Planetary Science Conference 34 ${ }^{\text {th }}$, March 2003, Houston, Texas, Extended Abstracts. Baragar, W.R.A., 1976, The Natkusiak basalts, Victoria Island, District of Franklin: Geological Survey of Canada Paper 76-1A, p. 347-352.

Bédard, J.H., Naslund, H.R., Nabelek, P., Winpenny, A., Hryciuk, M., Macdonald, W., Hayes, B., Steigerwaldt, K., Hadlari, T., Rainbird, R., Dewing, K., and Girard, É., 2012, Fault-mediated melt ascent in a Neoproterozoic continental flood basalt province, the Franklin sills, Victoria Island, Canada: Geological Society of America Bulletin, v. 124, p. 723-736.

Bédard, J.H., Hayes, B., Hryciuk, M., Wing, B., Beard, C., Dell'Oro, T.A., Weis, D., Scoates, J.S., Williamson, N., Cousens, B., Naslund, H.R., MacDonald, W., and Nabelek, P., 2013, The Neoproterozoic Franklin Large Igneous Province on Victoria Island: Geological Asssociation of CanadaMineralogical Association of Canada Annual Meeting, Program with Abstracts 35, p. 82.
Begg, G.C., Hronsky, J.A.M., Arndt, N.T., Griffin, W.L., O’Reilly, S.Y., and Hayward, N., 2010, Lithospheric, cratonic, and geodynamic setting of NiCu-PGE sulfide deposits: ECONOMIC GEOLOGY, v. 105, p. 1057-1070.

Black, B.A., Hauri, E.H., Elkins-Tanton, L.T., and Brown, S.M., 2014, Sulfur isotopic evidence for sources of volatiles in Siberian Traps magmas: Earth and Planetary Science Letters, v. 394, p. 58-69.

Borradaile, G.J., and Henry, B., 1997, Tectonic applications of magnetic susceptibility and its anisotropy: Earth Sciences, v. 42, p. 49-93.

Brenan, J.M., McDonough, W.F., and Dalpé, C., 2003, Experimental constraints on the partitioning of rhenium and some platinum-group elements between olivine and silicate melt: Earth and Planetary Science Letters, v. 212, p. $135-150$.

Buchanan, D.L., and Nolan, J., 1979, Solubility of sulfur and sulfide immiscibility in synthetic tholeiitic melts and their relevance to Bushveld-Complex rocks: Canadian Mineralogist, v. 17, p. 483-494.

Caine, J.S., Evans, J.P., and Forster, C.B., 1996, Fault zone architecture and permeability structure: Geology, v. 24, p. 1025-1028.

Campbell, I.H., and Naldrett, A.J., 1979, The influence of silicate:sulfide ratios on the geochemistry of magmatic sulfides: ECONOMIC GEOLOGY, v. 74 , p. $1503-1506$.

Capobianco, C.J., and Drake, M.J., 1990, Partitioning of ruthenium, rhodium, and palladium between spinel and silicate melt and implications for platinum group element fractionation trends: Geochimica et Cosmochimica Acta, v. 54, p. 869-874.

Cruden, A.R., Burrows, D.R., and Evans-Lamswood, D., 2008, Structure and emplacement of the Voisey's Bay troctolite and associated Ni-Cu-Co mineralisation [abs.]: Geological Association of Canada-Mineralogical Association of Canada-Society of Economic Geologists-Society of Geology Applied to Mineral Deposits, Quebec City, Quebec, May 26-28 2008, Program with Abstracts, p. 39.

Czamanske, G.K., and Moore, J.G., 1977, Composition and phase chemistry of sulfide globules in basalt from the Mid-Atlantic Ridge rift valley near $37^{\circ}$ N lat.: Geological Society of America Bulletin, v. 88, p. 587-599.

Delaney, P.T., and Pollard, D.D., 1981, Deformation of host rocks and flow of magma during growth of minette dikes and breccia-bearing intrusions near Ship Rock, New Mexico: U.S. Geological Survey Professional Paper $1202,61 \mathrm{p}$.

Dewing, K., Pratt, B.R., Hadlari, T., Brent, T., Bédard, J., and Rainbird, R.H., 2013, Newly identified "Tunnunik" impact structure, Prince Albert Peninsula, northwestern Victoria Island, Arctic Canada: Meteoritics and Planetary Science, v. 48 , p. 211-223.

Ding, X., Li, C., Ripley, E.M., Rossell, D., and Kamo, S., 2010, The Eagle and East Eagle sulfide ore-bearing mafic-ultramafic intrusions in the Midcontinent Rift System, Upper Michigan: Geochronology and petrologic evolution: Geochemistry, Geophysics, Geosystems, v. 11, Q03003.

Ding, X., Ripley, E., and Li, C., 2012, PGE geochemistry of the Eagle Ni-Cu(PGE) deposit, Upper Michigan: Constraints on ore genesis in a dynamic magma conduit: Mineralium Deposita, v. 47, p. 89-104.

Dostal, J., Baragar, W.R.A., and Dupuy, C., 1986, Petrogenesis of the Natkusiak continental basalts, Victoria Island, Northwest Territories, Canada: Canadian Journal of Earth Sciences, v. 23, p. 622-632.

Dupuy, C., Michard, A., Dostal, J., Dautel, D., and Baragar, W.R.A., 1995 Isotope and trace-element geochemistry of Proterozoic Natkusiak flood basalts from the northwestern Canadian Shield: Chemical Geology, v. 120, p. $15-25$

Durbano, A.M., Pratt, B.R., Hadlari, T., and Dewing, K., 2015, Sedimentology of an early Cambrian tide-dominated embayment: Quyuk formation, Victoria Island, Arctic Canada: Sedimentary Geology, v. 320, p. 1-18.

Ernst, R.E., and Baragar, W.R.A., 1992, Evidence from magnetic fabric for the flow pattern of magma in the Mackenzie giant radiating dyke swarm: Nature, v. 356 , p. 511-513.

Ernst, R.E., and Jowitt, S.M., 2013, Large igneous provinces (LIPs) and metallogeny: Society of Economic Geologists Special Publication 17, p. $17-51$.

Evans, J.P., Forster, C.B., and Goddard, J.V., 1997, Permeability of faultrelated rocks, and implications for hydraulic structure of fault zones: Journal of Structural Geology, v. 19, p. 1393-1404.

Finnigan, C.S., Brenan, J.M., Mungall, J.E., and McDonough, W.F., 2008, Experiments and models bearing on the role of chromite as a collector of platinum group minerals by local reduction: Journal of Petrology, v. 49, p. $1647-1665$.

Fiorentini, M.L., Bekker, A., Rouxel, O., Wing, B.A., Maier, W., and Rumble, D., 2012, Multiple sulfur and iron isotope composition of magmatic 
$\mathrm{Ni}-\mathrm{Cu}-(\mathrm{PGE})$ sulfide mineralization from eastern Botswana: ECONOMIC GEOLOGY, v. 107, p. 105-116.

Ganino, C., Arndt, N., Chauvel, C., and Tornos, F., 2014, Metamorphic degassing of carbonates in the contact aureole of the Aguablanca $\mathrm{Cu}-\mathrm{Ni}$ PGE deposit, Spain: Contributions to Mineralogy and Petrology, v. 168, p. $1-21$.

Giuliani, A., Phillips, D., Kamenetsky, V.S., Fiorentini, M.L., Farquhar, J., and Kendrick, M.A., 2014, Stable isotope (C, O, S) compositions of volatilerich minerals in kimberlites: A review: Chemical Geology, v. 374-375, p. $61-83$.

Glen, J.M.G., Renne, P.R., Milner, S.C., and Coe, R.S., 1997, Magma flow inferred from anisotropy of magnetic susceptibility in the coastal ParanáEtendeka igneous province: Evidence for rifting before flood volcanism: Geology, v. 25, p. 1131-1134.

Grinenko, L.I., 1985, Sources of sulfur of the nickeliferous and barren gabbro-dolerite intrusions of the northwest Siberian platform: International Geology Review, v. 27, p. 695-708.

Hastie, W.W., Watkeys, M.K., and Aubourg, C., 2014, Magma flow in dyke swarms of the Karoo LIP: Implications for the mantle plume hypothesis: Gondwana Research, v. 25, p. 736-755.

Haughton, D.R., Roeder, P.L., and Skinner, B.J., 1974, Solubility of sulfur in mafic magmas: ECONOMIC GEOLOGY, v. 69, p. 451-467.

Hayes, B., Bédard, J.H., and Lissenberg, C.J., 2015a, Olivine slurry replenishment and the development of igneous layering in a Franklin sill, Victoria Island, Arctic Canada: Journal of Petrology, v. 56, p. 83-112.

Hayes, B., Lissenberg, C.J., Bédard, J., and Beard, C., 2015b, The geochemical effects of olivine slurry replenishment and dolostone assimilation in the plumbing system of the Franklin large igneous province, Victoria Island, Arctic Canada: Contributions to Mineralogy and Petrology, v. 169, p. 1-18.

Heaman, L.M., LeCheminant, A.N., and Rainbird, R.H., 1992, Nature and timing of Franklin igneous events, Canada: Implications for a Late Proterozoic mantle plume and the break-up of Laurentia: Earth and Planetary Science Letters, v. 109, p. 117-131.

Hrouda, F., 1982, Magnetic anisotropy of rocks and its application in geology and geophysics: Geophysical Surveys, v. 5, p. 37-82.

Huber, H., Koeberl, C., McDonald, I., and Reimold, W.U., 2001, Geochemistry and petrology of Witwatersrand and Dwyka diamictites from South Africa: Search for an extraterrestrial component: Geochimica et Cosmochimica Acta, v. 65, p. 2007-2016.

Hughes, H.S.R., Boyce, A.J., McDonald, I., Davidheiser-Kroll, B., Holwell, D.A., McDonald, A., and Oldroyd, A., 2015, Contrasting mechanisms for crustal sulphur contamination of mafic magma: Evidence from dyke and sill complexes from the British Palaeogene igneous province: Journal of the Geological Society.

Hulbert, L., Rainbird, R., H., Jefferson, C.W., and Friske, P., 2005, Map of mafic and ultramafic bodies related to the Franklin magmatic event, Minto Inlier, Victoria Island: Geological Survey of Canada Open-File Map 4928, map scale sheet 1:1,000,000 + CD ROM.

Irvine, T.N., 1975, Crystallization sequences in the Muskox intrusion and other layered intrusions. II.Origin of chromitite layers and similar deposits of other magmatic ores: Geochimica et Cosmochimica Acta, v. 39, p. 991-1020.

Jefferson, C.W., Nelson, W.E., Kirkham, R.V., Reedman, J.H., and Scoates, R.F.J., 1985, Geology and copper occurrences of the Natkusiak basalts, Victoria Island, District of Frankalin: Geological Survey of Canada Paper 85-1A, p. 203-214.

Jefferson, C.W., Hulbert, L., Rainbird, R., H., Hall, G.E.M., Gregoire, D.C., and Grinenko, L.I., 1994, Mineral resource assessment of the Neoproterozoic Franklin igneous events of Arctic Canada: Comparison with the Permo-Triassic Noril'sk-Talnakh Ni-Cu-PGE deposits of Russia: Geological Survey of Canada Open-File Report 2789, 48 p.

Jowitt, S.M., and Ernst, R.E., 2013, Geochemical assessment of the metallogenic potential of Proterozoic LIPs of Canada: Lithos, v. 174, p. 291-307.

Jugo, P.J., Luth, R.W., and Richards, J.P., 2005, An experimental study of the sulfur content in basaltic melts saturated with immiscible sulfide or sulfate liquids at $1300^{\circ} \mathrm{C}$ and $1.0 \mathrm{GPa}$ : Journal of Petrology, v. 46, p. 783-798.

Keays, R., and Lightfoot, P., 2010, Crustal sulfur is required to form magmatic $\mathrm{Ni}$-Cu sulfide deposits: Evidence from chalcophile element signatures of Siberian and Deccan Trap basalts: Mineralium Deposita, v. 45, p. 241-257.

Kiss, F., and Oneschuk, D., 2010, First vertical derivative of the magnetic field, Minto Inlier aeromagnetic survey, Victoria Island, NTS $87 \mathrm{G} / \mathrm{SE}$ and parts of $87 \mathrm{G} / \mathrm{NW}, 88 \mathrm{~B} / \mathrm{SE}$ and $88 \mathrm{~B} / \mathrm{SW}$, Northwest Territories: Geological Survey of Canada Open-File Map 6705, scale 1:100,000.
Labidi, J., Cartigny, P., Hamelin, C., Moreira, M., and Dosso, L., 2014, Sulfur isotope budget (32S, 33S, 34S and 36S) in Pacific-Antarctic ridge basalts: A record of mantle source heterogeneity and hydrothermal sulfide assimilation: Geochimica et Cosmochimica Acta, v. 133, p. 47-67.

Leclerc, F., Bédard, J.H., Harris, L.B., McNicoll, V.J., Goulet, N., Roy, P., and Houle, P., 2011, Tholeiitic to calc-alkaline cyclic volcanism in the Roy Group, Chibougamau area, Abitibi Greenstone Belt-revised stratigraphy and implications for VHMS exploration: Geological Survey of Canada Contribution 20100254, Ministère des Ressources naturelles et de la Faune Contribution 8439-2010-2011-17, Canadian Journal of Earth Sciences, v. 48 , p. 661-694.

Lehmann, J., Arndt, N., Windley, B., Zhou, M.-F., Wang, C.Y., and Harris, C., 2007, Field relationships and geochemical constraints on the emplacement of the Jinchuan intrusion and its Ni-Cu-PGE sulfide deposit, Gansu, China: ECONOMIC GEOLOGY, v. 102, p. 75-94.

Li, C., and Naldrett, A.J., 1999, Geology and petrology of the Voisey's Bay intrusion: Reaction of olivine with sulfide and silicate liquids: Lithos, v. 47, p. 1-31.

Li, C., Lightfoot, P.C., Amelin, Y., and Naldrett, A.J., 2000, Contrasting petrological and geochemical relationships in the Voisey's Bay and Mushuau intrusions, Labrador, Canada: Implications for ore genesis: ECONOMIC GEOLOGY, v. 95, p. 771-799.

Li, C., Xu, Z., de Waal, S., Ripley, E., and Maier, W., 2004, Compositional variations of olivine from the Jinchuan $\mathrm{Ni}$-Cu sulfide deposit, western China: Implications for ore genesis: Mineralium Deposita 39, 159-172.

Li, C., Ripley, E.M., and Naldrett, A.J., 2009, A new genetic model for the giant Ni-Cu-PGE sulfide deposits associated with the Siberian flood basalts: ECONOMic GeOlogY, v. 104, p. 291-301.

Lightfoot, P.C., and Evans-Lamswood, D., 2015, Structural controls on the primary distribution of mafic-ultramafic intrusions containing $\mathrm{Ni}-\mathrm{Cu}-\mathrm{Co}-$ (PGE) sulfide mineralization in the roots of large igneous provinces: Ore Geology Reviews, v. 64, p. 354-386.

Liu, Y., Samaha, N.-T., and Baker, D.R., 2007, Sulfur concentration at sulfide saturation (SCSS) in magmatic silicate melts: Geochimica et Cosmochimica Acta, v. 71, p. 1783-1799.

Macdonald, F.A., Schmitz, M.D., Crowley, J.L., Roots, C.F., Jones, D.S., Maloof, A.C., Strauss, J.V., Cohen, P.A., Johnston, D.T., and Schrag, D.P., 2010, Calibrating the Cryogenian: Science, v. 327, p. 1241-1243.

Maier, W.D., Li, C., and De Waal, S.A., 2001, Why are there no major Ni-Cu sulfide deposits in large layered mafic-ultramafic intrusions?: Canadian Mineralogist, v. 39, p. 547-556.

Mathieu, J., Kontak, D.J., and Turner, E.C., 2013, A fluid inclusion study of diagenetic fluids in Proterozoic and Paleozoic carbonate rocks, Victoria Island, NWT: Geofluids, v. 13, p. 559-578.

McDonald, I., and Viljoen, K.S., 2006, Platinum-group element geochemistry of mantle eclogites: A reconnaissance study of xenoliths from the Orapa kimberlite, Botswana: Applied Earth Science, v. 115, p. 81-93.

McDonough, W.F., and Sun, S.s., 1995, The composition of the Earth: Chemical Geology, v. 120, p. 223-253.

Miller, J.D., Green, J.C., Severson, M.J., Chandler, V.W., Hauck, S.A., Peterson, D.M., and Wahl, T.E., 2002, Geology and mineral potential of the Duluth Complex and related rocks of northeastern Minnesota: Minnesota Geological Survey Report of Investigations 58, 207 p.

Mungall, J.E., 2007, Crustal contamination of picritic magmas during transport through dikes: The expo intrusive suite, Cape Smith fold belt, New Quebec: Journal of Petrology, v. 48, p. 1021-1039.

Nabelek, P.I., Bédard, J.H., Hryciuk, M., and Hayes, B., 2013, Short-duration contact metamorphism of calcareous sedimentary rocks by Neoproterozoic Franklin gabbro sills and dykes on Victoria Island, Canada: Journal of Metamorphic Geology, v. 31, p. 205-220.

Naldrett, A.J., 1992, A model for the Ni-Cu-PGE ores of the Noril'sk region and its application to other areas of flood basalt: ECONOMIC GEOLOGY, v. 87, p. $1945-1962$.

1999, World-class Ni-Cu-PGE deposits: Key factors in their genesis: Mineralium Deposita, v. 34, p. 227-240.

2004, Magmatic sulfide deposits: Geology, geochemistry and exploration: Heidelberg, Berlin, Springer Verlag, $728 \mathrm{p}$.

Naldrett, A.J., Asif, M., Krstic, S., and Li, C., 2000, The composition of mineralization at the Voisey's Bay Ni-Cu sulfide deposit, with special reference to platinum-group elements: ECONOMIC GEOLOGY, v. 95, p. 845-865.

Naslund, H.R., Bédard, J.H., Steigerwaldt, K., and Dye, D., 2013, Origin of S and $\mathrm{M}$ and reversed $\mathrm{S}$ and $\mathrm{M}$ shaped profiles in two Proterozoic mafic sills 
from the Franklin magmatic event, Victoria Island, NWT, Canada [abs.]: Geophysical Research, Abstracts 15.

Palmer, H.C., Ernst, R.E., and Buchan, K.L., 2007, Magnetic fabric studies of the Nipissing sill province and Senneterre dykes, Canadian shield, and implications for emplacement: Canadian Journal of Earth Sciences, v. 44, p. 507-528.

Peterson, R.C., Williamson, M.-C., and Rainbird, R.H., 2014, Gossan Hill, Victoria Island, Northwest Territories: An analogue for mine waste reactions within permafrost and implication for the subsurface mineralogy of Mars: Earth and Planetary Science Letters, v. 400, p. 88-93.

Prince, J.K.G., 2014, Sequence stratigraphic, lithostratigraphic and stable isotope analysis of the Minto Inlet Formation and Kilian Formation, of the Shaler Supergroup, Northwest Territories: Thesis, Ottawa, Carleton University, $127 \mathrm{p}$.

Rainbird, R., 1993, The sedimentary record of mantle plume uplift preceding eruption of the Neoproterozoic Natkusiak flood basalt: Journal of Geology, v. 101 , p. $305-318$.

Raposo, M.I.B., and Ernesto, M., 1995, Anisotropy of magnetic susceptibility in the Ponta Grossa dyke swarm (Brazil) and its relationship with magma flow direction: Physics of the Earth and Planetary Interiors, v. 87, p. 183-196.

Ripley, E.M., and Li, C., 2003, Sulfur isotope exchange and metal enrichment in the formation of magmatic $\mathrm{Cu}-\mathrm{Ni}$-(PGE) deposits: ECONOMIC GEOLOGY, v. 98 , p. $635-641$.

2011, A review of conduit-related $\mathrm{Ni}-\mathrm{Cu}$-(PGE) sulfide mineralization at the Voiseys Bay deposit, Labrador, and the Eagle deposit, northern Michigan: Reviews in Economic Geology, v 17.

2013, Sulfide saturation in mafic magmas: Is external sulfur required for magmatic Ni-Cu-(PGE) ore genesis?: ECONOMIC GEOLOGY, v. 108, p. $45-58$.

Ripley, E.M., Lightfoot, P.C., Li, C., and Elswick, E.R., 2003, Sulfur isotopic studies of continental flood basalts in the Noril'sk region: Implications for the association between lavas and ore-bearing intrusions: Geochimica et Cosmochimica Acta, v. 67, p. 2805-2817.

Ripley, E.M., Sarkar, A., and Li, C., 2005, Mineralogic and stable isotope studies of hydrothermal alteration at the Jinchuan Ni-Cu deposit, China: ECONOMIC GEOLOGYv. 100, p. 1349-1361.

Rivalta, E., Taisne, B., Bunger, A.P., and Katz, R.F., 2015, A review of mechanical models of dike propagation: Schools of thought, results and future directions: Tectonophysics, v. 638, p. 1-42.

Robertson, J., Ripley, E.M., Barnes, S.J., and Li, C., 2015, Sulfur liberation from country rocks and incorporation in mafic magmas: ECONOMIC GEOLOGY, v. 110, p. 1111-1123.

Saumur, B.M., Cruden, A.R., Evans-Lamswood, D., and Lightfoot, P.C., 2015, Wall-rock structural controls on the genesis of the Voisey's Bay intrusion and its Ni-Cu-Co magmatic sulfide mineralization (Labrador, Canada): ECONOMIC GEOLOGY, v. 110, p. 691-711.
Scoates, J.S., and Mitchell, J.N., 2000, The evolution of troctolitic and high Al basaltic magmas in Proterozoic anorthosite plutonic suites and implications for the Voisey's Bay massive Ni-Cu sulfide deposit: ECONOMIC GEOLOGY, v. 95, p. $677-701$.

Seat, Z., Beresford, S.W., Grguric, B.A., Gee, M.A.M., and Grassineau, N.V., 2009, Reevaluation of the role of external sulfur addition in the genesis of Ni-Cu-PGE deposits: Evidence from the Nebo-Babel Ni-Cu-PGE deposit, West Musgrave, Western Australia: Economic Geology, v. 104, p. 521-538.

Song, X.-Y., Danyushevsky, L., Keays, R., Chen, L.-M., Wang, Y.-S., Tian, Y.-L., and Xiao, J.-F., 2012, Structural, lithological, and geochemical constraints on the dynamic magma plumbing system of the Jinchuan $\mathrm{Ni}-\mathrm{Cu}$ sulfide deposit, NW China: Mineralium Deposita, v. 47, p. 277-297.

Sun, S.S., and McDonough, W.F., 1989, Chemical and isotopic systematics of oceanic basalts: Implications for mantle composition and processes: Geological Society, London, Special Publication 42, p. 313-345.

Tarling, D.H., and Hrouda, F., 1993, The magnetic anisotropy of rocks: London, Chapman and Hall, $217 \mathrm{p}$.

Thomson, D., Rainbird, R.H., and Dix, G., 2014, Architecture of a Neoproterozoic intracratonic carbonate ramp succession: Wynniatt Formation, Amundsen basin, Arctic Canada: Sedimentary Geology, v. 299, p. 119-138.

Thorsteinsson, R., and Tozer, E.T., 1962, Banks, Victoria and Stefansson Islands, Arctic Archipelago: Geological Survey of Canada Memoir 330, 85 $\mathrm{p}$

Tredoux, M., Lindsay, N.M., Davies, G., and McDonald, I., 1995, The fractionation of platinum-group elements in magmatic systems, with the suggestion of a novel causal mechanism: South African Journal of Geology, v. 98 , p. $157-167$.

Wendlandt, R.F., 1982, Sulfide saturation of basalt and andesite melts at high pressures and temperatures: American Mineralogist, v. 67, p. 877-885.

Williamson, N., Bédard, J.H., Ootes, L., Rainbird, R., Cousens, B., and Zagorevski, A., 2013, Volcanostratigraphy and significance of the southern lobe Natkusiak Formation flood basalts, Victoria Island, Northwest Territories: Geological Survey of Canada, Current Research 2013-16, 13 p.

Young, G.M., 1981, The Amundsen embayment, Northwest Territories, relevance to the Upper Proterozoic evolution of North America: Geological Survey of Canada Paper 81-10, p. 203-211.

Žák, J., Verner, K., Johnson, K., and Schwartz, J.J., 2012, Magma emplacement process zone preserved in the roof of a large Cordilleran batholith, Wallowa Mountains, northeastern Oregon: Journal of Volcanology and Geothermal Research, v. 227-228, p. 61-75. 
